Article

\title{
Rainwater Harvesting Potential and Utilization for Artificial Recharge of Groundwater Using Recharge Wells
}

\author{
Fiaz Hussain ${ }^{1}$, Riaz Hussain ${ }^{2}$, Ray-Shyan $\mathrm{Wu}^{1, *}$ and Tanveer Abbas ${ }^{3}$ \\ 1 Department of Civil Engineering, National Central University, Chung-Li 32001, Taiwan; \\ engr.fiaz@uaar.edu.pk \\ 2 Strategic Policy Unit (SPU), LDA Lahore 54890, Pakistan; riazuaf@hotmail.com \\ 3 MM Pakistan (Pvt) Ltd., Lahore 54890, Pakistan; tanveer.abbas6@gmail.com \\ * Correspondence: raywu@ncu.edu.tw; Tel.: +886-3-4227151 (ext. 34126)
}

Received: 10 August 2019; Accepted: 11 September 2019; Published: 16 September 2019

\begin{abstract}
This study devised a practical solution to mitigate urban inundation and artificial recharge of groundwater using recharge wells which is the most viable surface runoff rainwater harvesting (RWH) technique in urban areas. The Rainwater Harvesting Pilot Project at Gaddafi Stadium Lahore was established to deal with urban flooding, artificial recharge of groundwater, and to avoid the mixing of rainwater in municipal sewerage. The study showed that Lahore city has great RWH potential from critical ponding roads that can be utilized to recharge the Lahore aquifer. With that ratio of recharge, the groundwater level can rise to $3.54 \mathrm{ft}$ after every monsoon period if the same recharge wells structure are used, which is a key to groundwater sustainability in Lahore city. Moreover, the maximum recharging capacity of wells was $29.32 \mathrm{~m}^{3} / \mathrm{h}$ with satisfactory performance. Both recharge wells cleared the ponding volume within 3 to $3.5 \mathrm{~h}$ after the rainfall stopped. The filter media performance was also favorable with $25 \%-30 \%$ removal of contamination. All the water quality parameters were within the permissible limit against prescribed standards except coliform count that indicated the presence of sewage. In such a case the mixing of charcoal is recommended to shut up the coliform signals. This study identified that RWH using recharge wells is an alternative freshwater supply source for sustainable development of Lahore city and this technique should be the part of Master Planning and Policy Decision of Lahore as a suggestion.
\end{abstract}

Keywords: urban inundation; Lahore city; RWH; artificial recharge wells

\section{Introduction}

Water and roads are the lifelines of socio-economic and sustainable developments in urban areas. When the roads remain inundated for many hours due to heavy storm events this leads to massive traffic jams. This chaos on the roads brings misery to socio-economic life. The global demographic trend shifting toward urban areas is resulting in the world water crisis, especially in cities. According to the UN-HABITAT report on rainwater harvesting and utilization, more than half of population is going to be urbanized by 2025 and it will be a significantly challenging task for water managers and policymakers to provide adequate and equitable water supply to meet societal needs [1]. These factors have pushed more efforts towards groundwater over-abstraction and exploitation due to its ubiquitous occurrence, easy availability, and reliability in urban areas. This overdraft of groundwater leads to a decline in groundwater level as well as a water shortage for urban dwellers [2]. For a case in point, Pakistan's big cities are facing such problems due to rapid population growth, along with urbanization, industrialization, agricultural intensification, and changing lifestyles. This increasing demand of population cannot be met with scare surface water, which resulted in increased groundwater 
abstraction to fulfil the requirement of the domestic, industrial, and agriculture sectors in Pakistan from last few decades on account of its ubiquitous occurrence, easy availability, and reliability [3]. These qualities have led to its indiscriminate exploitation in dense urban areas of the country such as Lahore without due regard to recharging options. The reckless use of groundwater further aggregates the water scarcity problems, which is a major concern for long term sustainability. To date, more attention has been given to centralized approaches (finding alternative or additional water resources) as compared to decentralized approaches (optimizing water management systems) by water managers and policymakers for fulfilment of sustainable management of freshwater in urban areas. There is an urgent need for development and implementation of water resources management through decentralized approaches such as rainwater harvesting and utilization using artificial recharge structure. This engineering solution for freshwater problems has been proven as a viable option for augmentation of groundwater resources [4-7].

This study mainly focuses on Lahore city, the second-largest urban hub of Pakistan. The city area is facing two severe problems, one is the rapid decline in groundwater level due to extensive extraction of groundwater and the other is regular flooding in the city area during monsoon season. Its expansion over time is owed to several vectors of growth, for example, available land for settlements, commercialization, and industrial expansion. Over the last two decades, and more importantly since the mid of 1990s, private housing has taken the lead to increase the footprint of Lahore across all available directions. Resultantly, open and agricultural land continues to be converted to building structures, networking of roads, and paved areas. This mushrooming of concrete jungle does not permit recharging of groundwater in such a manner and, importantly, that is essential to its sustainability. Further, this rapid urbanization aggregated the urban runoff problem which is the main reason for regular flooding in the city area during monsoon rainfall season. It was observed that during the rainy season the fresh rainwater swapped over roofs, streets, parking lots, roads, and paved areas and became the part of sewage and drain as an extra load causing overflows of sewerage and drainage systems. This situation becomes problematic for the public movement and creates unwanted traffic hazards for hours. Municipal authorities have put their efforts to pump out poundage rainwater in low lying areas to clean roads which may cause health-related issues including dengue and malaria $[8,9]$.

The only source of water supply in Lahore city is groundwater aquifer. Currently, a total of 1800 public and private tube wells having a design capacity of approximately 2900 acre-feet (AF) are extracting about $3500 \mathrm{AF}$ water per day. Due to this extensive extraction of groundwater, the groundwater table is rapidly depleting by an average rate of $3.03 \mathrm{ft}$ per annum $[9,10]$. These facts combined with the scarcity of clean drinking water draws urgent attention to devise new ways of response for increasing water demand of the city and conserving aquifer. Artificial recharge to groundwater through recharge wells is a viable option for rainwater harvesting (RWH) and utilization in Lahore city for augmentation of groundwater resources (rise in groundwater table) which also save energy (because $1 \mathrm{~m}$ rise in water level saves $0.4 \mathrm{Kwh}$ of electricity) [11]. Subsequently, this technique also reduces storm drainage and sewerage system load on existing drainage facilities.

The concept of RWH is not new [12], in many parts of the world it is frequently used to deal with water scarcity and urban flooding. It is an important source of recharging the groundwater which can be used for drinking and non-drinking purposes including irrigation and farming [13-18]. The history related to growing global interest in RWH after 1980s indicated that the RWH technique is now being given more attention and has equal popularity in the western and eastern world. Over the past four decades, the number of studies related to RWH has increased exponentially. These studies have been carried out in Australia [19], Brazil [20], China [21,22], Greece [23], India [24,25], Bangladesh [26,27], Iran [28,29], Pakistan [30-32], Indonesia [33], Hawaii [34], Kenya [35], Thailand [36,37], Germany [38], Guatemala [39], Ireland [40], Jordan [41], Namibia [42], Singapore [43,44], Malaysia [45], South Africa [46], Spain [47], Sweden [48], UK [49], USA [50], Taiwan [16], and Zambia [51], to name a few. These extensive studies indicated that RWH has many benefits related to the economy, the environment, technology, and society. Based on the findings from the literature review that rainwater is a fresh 
source for recharging groundwater and a soft approach to deal with urban flooding, this study mainly is composed of surface runoff RWH system for flood mitigation in an urban catchment of Lahore. The main objectives of the study are utilization of the rainwater for groundwater recharge with other multipurpose activities, such as avoiding rainwater discharge in municipal sewers, devising policy for appropriate rainwater harvesting system in Lahore, studying and designing rainwater harvesting techniques (collection, storage, groundwater recharge) under varying local conditions, and finding out a solution to deal with ponding of rainwater in Lahore. To the best of our knowledge, this is the first study for surface runoff harvesting to mitigate flood inundation in Lahore city which will be helpful for policymakers and water managers. The workflow methodology comprised of (i) an overview of existing inundation condition of Lahore city, (ii) identification of ponding sites and inundation conditions during monsoon season, and (iii) estimation of RWH potential from roads runoff, (iv) pre-harvesting measures for the design of recharge well and harvesting rainwater, (v) post-harvesting measures, and (v) conclusions and recommendations.

\section{Materials and Methods}

This study devised a practical solution to mitigate the urban flooding and use of rainwater runoff for the recharge of groundwater in Lahore city. For this purpose, a straightforward methodology is proposed for the achievement of desired objectives.

After the overview of the existing inundation condition of Lahore city, the methodology moves towards identification of ponding sites. The identification of ponding sites was done based on available recorded information from Water and Sanitation Agency (WASA) Lahore and other related reports. Moreover, during the monsoon period, a field survey and interviews of local inhabitants were carried out to collect information about the existing drainage system, ponding depth and area, ponding time, WASA existing arrangements, and opinion/suggestions of area residents. The field survey helped to find out rainwater harvesting potential from main roads having critical ponding depth as discussed in Section 3.1. The second part of the methodology deals with rainwater harvesting utilization for artificial recharge of groundwater. The main write up consists of pre-and post-harvesting measures. Pre-harvesting measures are as follows: (i) analysis of groundwater mass balance of Lahore city, (ii) drinking water quality analysis, (iii) rainwater quality analysis, (iv) rainwater runoff estimation for mitigation of inundation, (v) filter media design and its performance analysis for RWH and (vi) design and installation of recharge well. Post-harvesting measures are related to performance evaluation of recharge wells based on recharge rate and ponding area clearance time, and water quality analysis of recharged water. The groundwater pumping and recharge data was collected from WASA, Lahore reports. Rainwater and drinking water samples were collected during the monsoon season and sent to Pakistan Council of Scientific and Industrial Research (PCSIR) and Pakistan Council of Research in Water Resources (PCRWR) scientific laboratories for analysis of Physico-Aesthetic Chemical and Microbiological analysis of samples. One-day maximum rainfall data was collected from Pakistan Meteorological Department (PMD) Lahore office for rainwater runoff estimation. The designing and construction of recharge wells were done under Rainwater Harvesting Pilot Project at Gaddafi Stadium Lahore on Engineering Procurement Construction (EPC) basis by Lahore Development Authority (LDA) and data were collected related to performance of recharge wells. The performance of the filter mechanism of recharge wells was evaluated by an experimental setup. A detailed description of every section is mentioned below.

\subsection{Overview of the Existing Inundation Condition of Lahore City}

Lahore is a provincial headquarter of Punjab province, having an estimated population of 11.13 million with total area of $1772 \mathrm{~km}^{2}$. Its catchment area received an average annual rainfall of $629 \mathrm{~mm}$ of which $74.7 \%$ ( $470 \mathrm{~mm}$ ) occurred in the monsoon season. Generally, monsoon rainfall is the cause of runoff in urban and rural areas of the Lahore district. In order to cope with rainfall-runoff in urban areas, a comprehensive drainage network comprising main drains along with secondary and tertiary drains 
exists which mostly outfall in river Ravi. However, with population influx and enhanced construction activities, the drainage areas were deformed and only a few reaches of areas flow directly into the drains. Unfortunately, the influx of population in the surrounding areas finds convenient disposal of their sewage into these carriers. Accordingly, sewers load the drains throughout the year while stormwater flows are carried during the rainy season (three months) in a year. As such, the original stormwater drains have now become sewage drains. Under the existing conditions, the combined flows during dry and wet weather are drained from the hose connection in the streets up to the drain in the area. Additionally, it is observed that due to enormous construction activities the drainage areas may not fully tend to accept rainfall-runoff directly to the respective drain. Consequently, the fresh rainwater swaps over roofs, streets, parking lots, roads and paved areas and becomes part of sewage and drain as an extra load (Figure 1a) causing overflows of the sewerage and drainage system which directly (via pumping) or through a lift station is discharged into the drains (Figure 1b). Their operation as a separate system of rainfall-runoff and sewage flows is only possible if the separate arrangements start at the consumer end, which is not the case under present conditions.

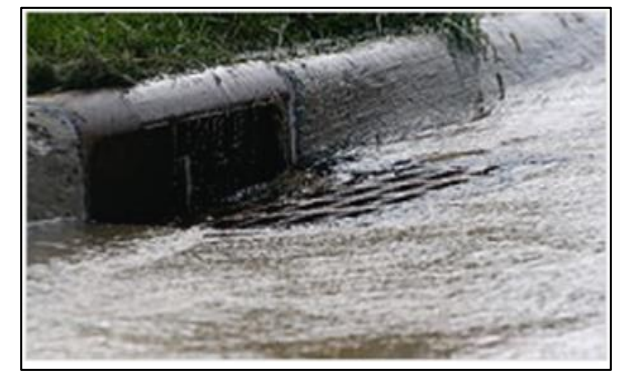

(a)

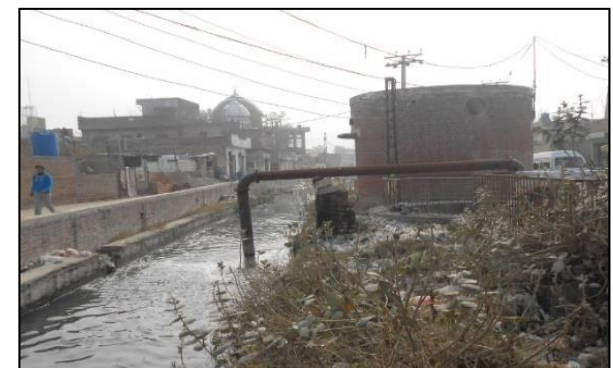

(b)

Figure 1. (a) Urban runoff flowing into the sewer drain; (b) sewage outfall into the Charar drain

Stormwater drainage in densely populated areas of Lahore has been a major environmental hazard and civic problem. The situation becomes worst in the monsoon season which normally extends from July to September every year. The rainfall-runoff rushes along the roads towards the relatively low-lying areas and gets accumulated speedily to form ponding areas, where evacuation through surface drainage is not always possible. The impounded runoff is ultimately drained through the sewerage system provided by WASA in the area. These critically ponded areas are in the limelight during extreme events with inundation of large residential and commercial pockets within the city (Figure 2a). The surface drainage system is inadequate to cater to this mass of water thereby further aggravating the situation. In the present situation, these ponding areas are drained through the existing system and take about 4 to $8 \mathrm{~h}$ to evacuate the area. This situation becomes problematic for the public movement and creates unwanted traffic hazards for hours (Figure 2b).

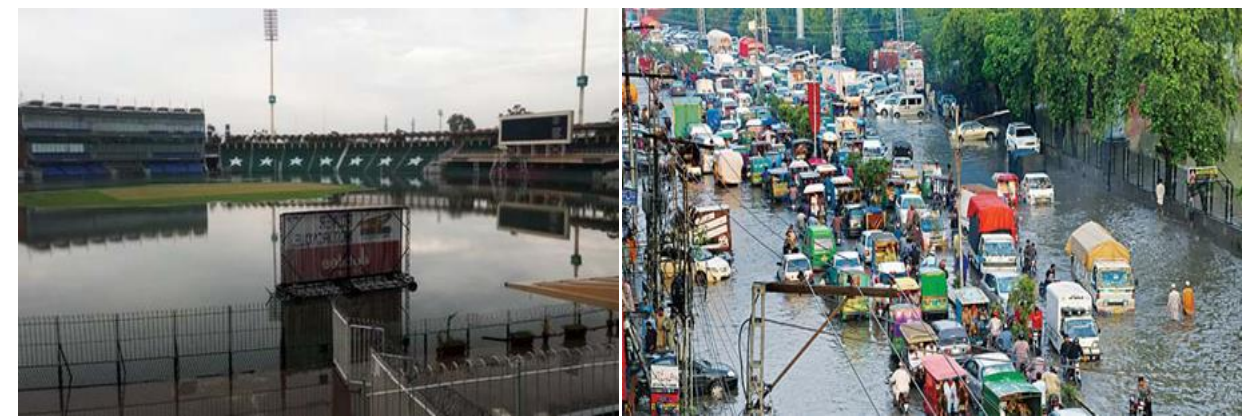

(a) (b)

Figure 2. (a) Ponding condition inside Gaddafi Stadium; (b) a traffic mess on Circular road after rainfall (DAWN news) 


\subsection{Identification of Ponding Sites}

Lahore city is still continuously ravaged by a series of urban flooding despite structural measures that have been implemented to counter this calamity. This is a grim reminder that man has not yet proven itself equal against the forces of nature. For the identification of ponding sites in urban localities, the initial information was collected from WASA Lahore. As per the WASA data record, there are in total 51 depressed locations that form ponding areas during rainfall, of which 28 had been treated to minimize the ponding time and 23 remaining locations are under consideration for rectification. However, from the survey conducted during the monsoon season, it is evident that there are numerous critical ponding locations in densely populated, commercial areas of Lahore which need rectification and proper solution for runoff harvesting. During the monsoon period, a survey was conducted, and 118 ponding locations were identified across the Lahore district (Figure 3). Some of the ponding was very minor ( $2-3$ inch) and ponding time is very small. In some of the ponding areas, the ponding time has been reduced after some remedial measures by WASA. Of the 118 ponding areas, 43 sites have a critical ponding location with ponding depth more than 3 inches. During the study, different main roads of Lahore were observed using Google Earth software. The longitudinal elevation profile (Figure 4) with the difference in elevation of the depression areas were revealed through this technique. These depressed areas undergo flooding during heavy rainfall events as shown in Figure 5 . The longitudinal elevation profiles analysis became helpful for the verification of ponding depth at identified ponding locations.

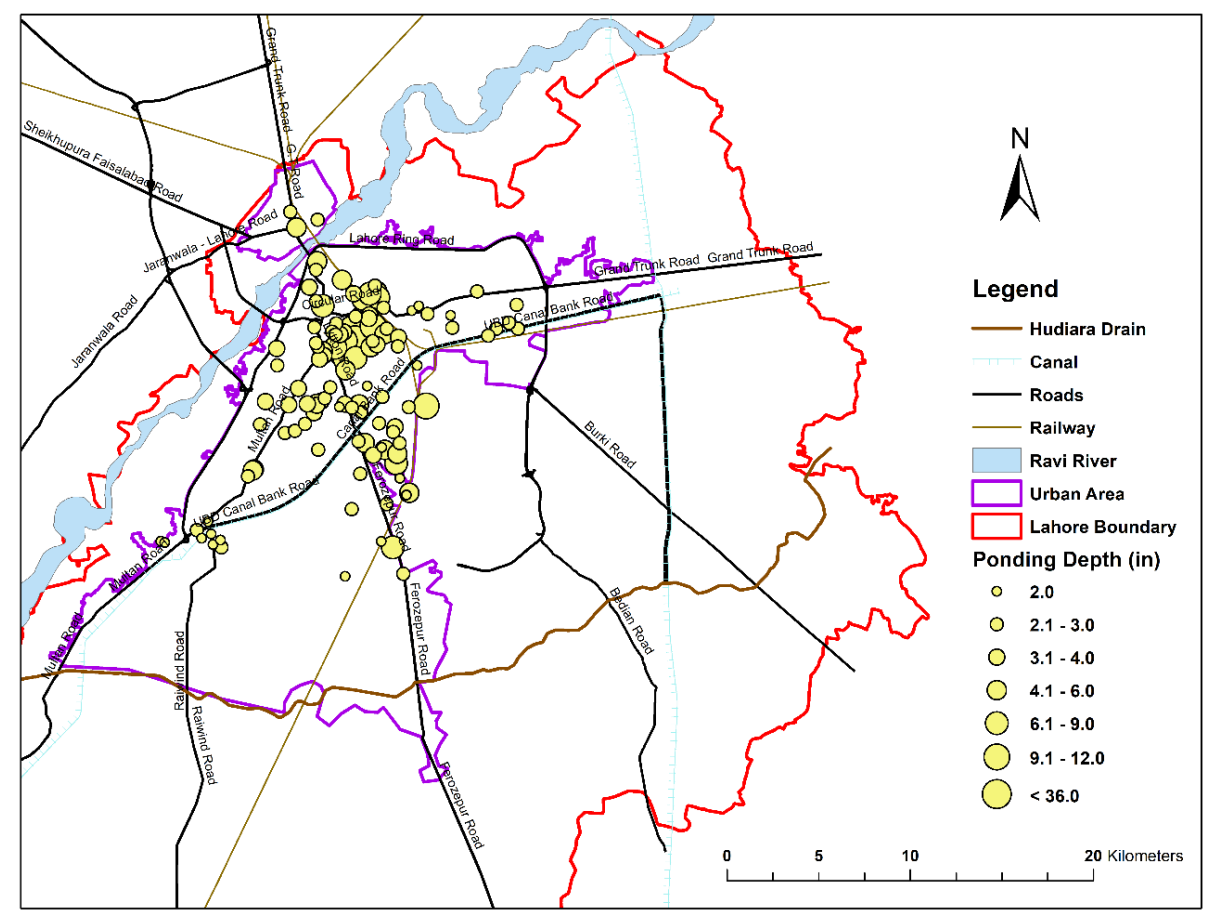

Figure 3. Location of ponding sites and ponding depth. 


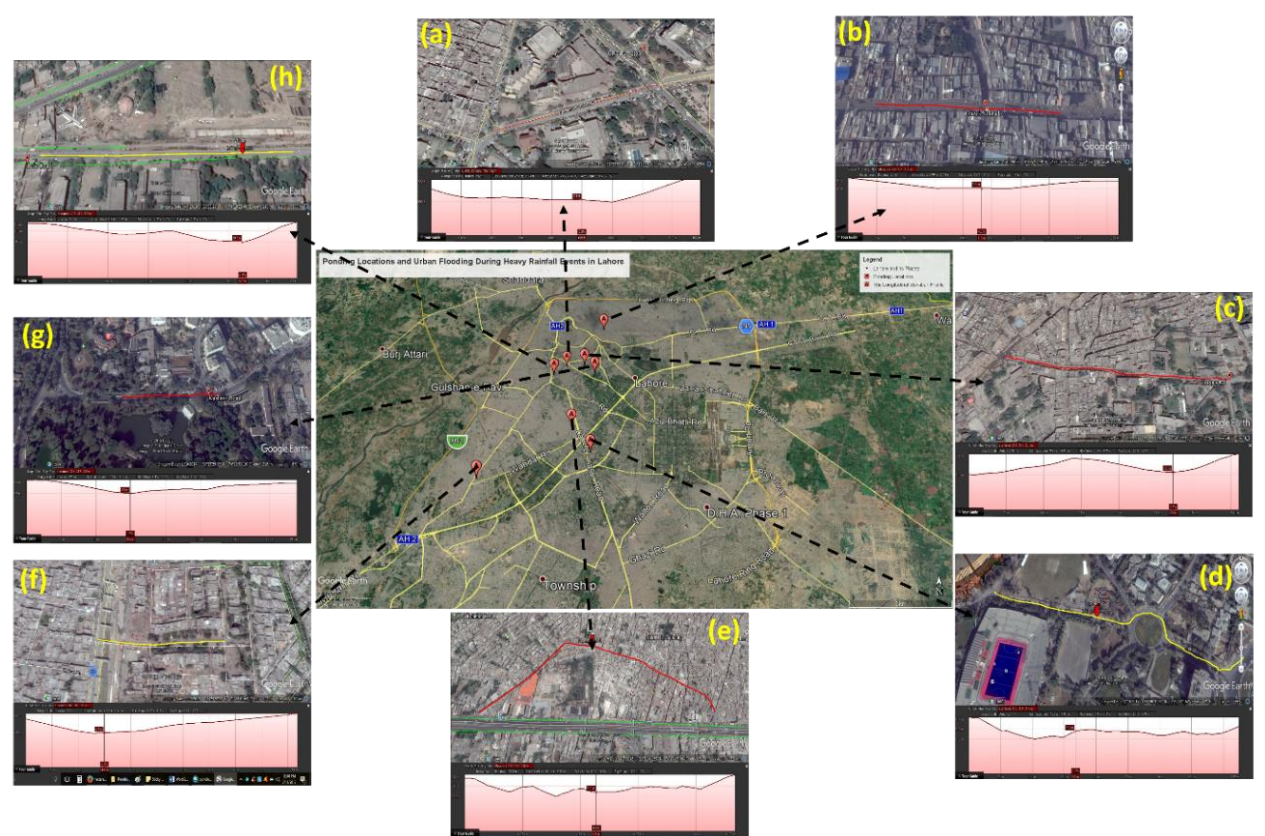

Figure 4. Longitudinal profiles of roads having flood inundation during monsoon. (a) GPO Bus stop ponding area (length $=270 \mathrm{~m}$, slope $=13.4 \%$ ); (b) Chowk Nakhuda ponding area (length $=235 \mathrm{~m}$, slope $=2.8 \%)$; (c) Cooper Road ponding area (length $=541 \mathrm{~m}$, slope $=6.3 \%$ ); (d) Gaddafi Stadium ponding area (length $=637 \mathrm{~m}$, slope $=6.3 \%$ ); (e) Sultan Ahmed Road ponding area (length $=1.17 \mathrm{~km}$, slope $=3.6 \%$; (f) Fruit and Vegetable Market Multan Road (length = $259 \mathrm{~m}$, slope $=32.7 \%$ ); (g) Kashmir Road ponding area (length $=195 \mathrm{~m}$, slope $=8.4 \%$ ); (h) Lake Road ponding area (length $=335 \mathrm{~m}$, slope $=12.2 \%$ ).

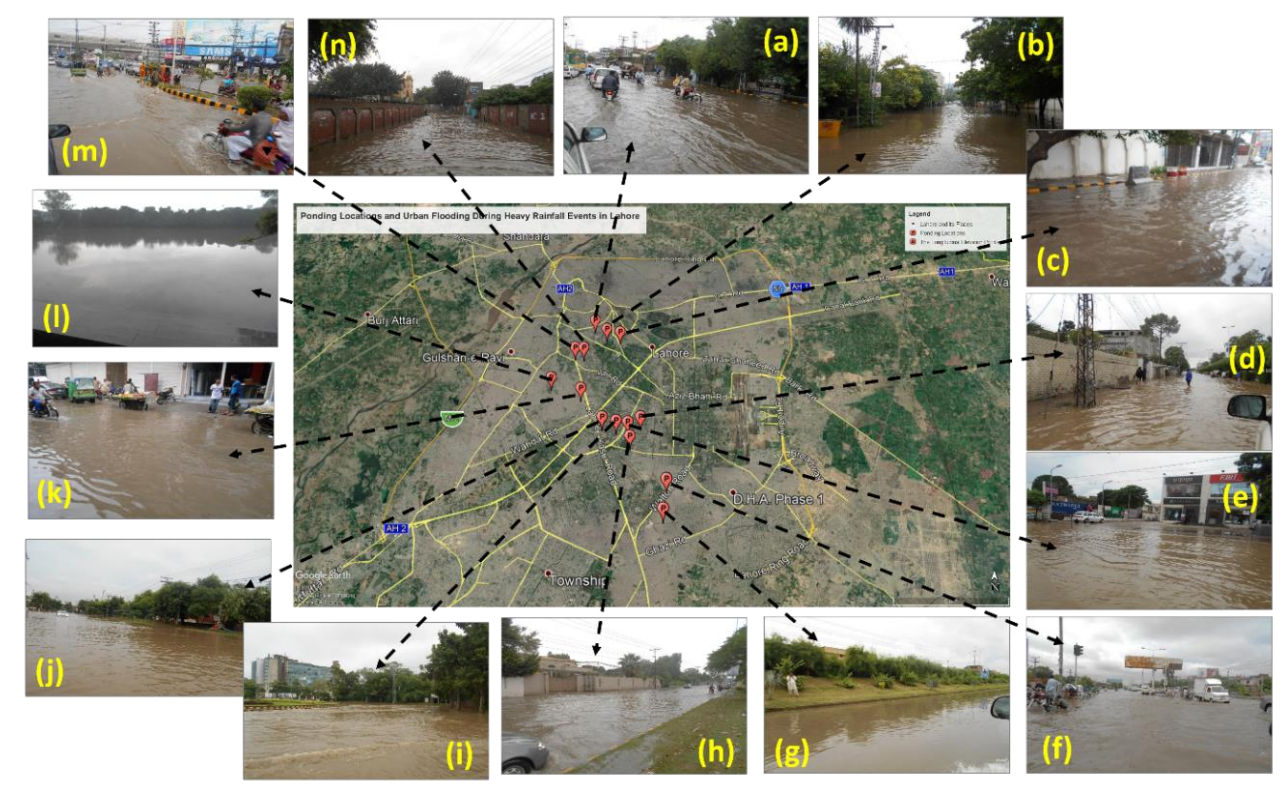

Figure 5. Inundation condition and depth on ponding roads during monsoon season (a) Cooper Road (ponding depth = 10 inch); (b) Kashmir Road (ponding depth = 8 inch); (c) Davis Road (ponding depth = 6 inch); (d) MM.Alam Road (ponding depth $=4$ inch); (e) Liberty Market (ponding depth = 6 inch); (f) Walton Road (ponding depth = 8 inch); (g) Khayaban-e-Iqbal Road (ponding depth $=6$ inch); (h) Ali Zaib Road (ponding depth = 8 inch); (i) Hafeez Kardar Road and Roundabout (ponding depth = 8 inch); (j) Gaddafi Stadium (ponding depth = 6 inch); (k) Sultan Ahmed Road (ponding depth = 6 inch); (1) Doongi Ground (ponding depth = 10 inch); (m) Qartuba Chowk, Mazang Chungi (ponding depth $=8$ inch); (n) Waris Road (ponding depth $=6$ inch). 
A field survey of all identified ponding locations indicated that 25 ponding sites have a ponding depth more than $0.5 \mathrm{ft}$ of which nine sites have a ponding depth up to $2 \mathrm{ft}$. The names are given as Faletti's Hotel Backside, Fortress Stadium Circular Rd, Govt Islamia College Coper Rd, Dyal Singh College Lakshmi Chowk, Haji Camp Empress Rd, Muslim League High School Empress Rd, Queen's Rd, Hall Rd, and Backside Barkat Market. Dyal Singh College Lakshmi Chowk has a maximum ponding up to $3 \mathrm{ft}$ during the monsoon rainfall period, as shown in Figure 3. The Google Earth elevation profile map also verified these depths such as a typical depression near the General Post Office (GPO) Bus Stop. The GPO Bus Stop is situated in front of the GPO building on Ustad Allah Bakhsh road. The depression area length covers almost $270 \mathrm{~m}$ along the road. The slope of depression area is 0.013 which receives runoff flows at the GPO Bus Stop from both sides of the road. Similarly, at Hafeez Kardar road, near Gaddafi Stadium, indicates a $6.2 \%$ slope along $637 \mathrm{~m}$ of long road and a ponding depth of almost 6 inches, as shown in Figures $4 d$ and $5 j$.

Based on field observation and interview with the inhabitants, the following major problems were addressed which cause the formation of ponding areas. (i) Inadequate capacity of sewer/drain, (ii) siltation of sewer/drain, (iii) no provision of drain/sewer, (iv) no provision of inlet, (v) depressions converging to a particular location, and (vi) topographic variation within the city areas as some of the areas (Lakshami, Tajpura) are in depression which form the ponding area. The major cause of the ponding area formation is unlevelled roads. In many places, the primary roads are elevated while the secondary and tertiary roads are in depression. The rainfall-runoff rushes to the depressed location and gets accumulated to form the ponding area which remains thereafter rains. Due to inadequacy of the existing drainage system, some of the depressed locations in thickly populated and commercial areas in Lahore have emerged as very critical points.

\subsection{Estimation of RWH Potential}

The estimation of RWH potential was done from critical ponding roads in this study. From 118 observed ponding locations, a total of 43 sites were separated by considering more than 3-inch ponding depth as a scrutinizing criterion. The detail about the inundation area and ponding depth of critical selected sites is shown in Table 1.

\subsection{Artificial Recharge of Groundwater}

The capturing of rainfall runoff from the roads and creating artificial connectivity to groundwater in a hygienic manner is the key concept for designing the recharge wells of the RWH system. Artificial recharge is the process of infiltrating the rainwater into sub-surface by constructing civil structures such as recharge wells. The designing and construction of recharge wells was done by considering the following preliminary work.

Rainwater Runoff Estimation for Design of Recharge Wells

The peak rainwater runoff estimation was done using the US-SCS Curve Number (SCS-CN) method. Gaddafi Stadium ponding site was selected because of site suitability for construction of the recharge wells and one of the priority sites by WASA and LDA Lahore. The SCS-CN method required the following information about the selected site.

Maximum $24 \mathrm{~h}$ rainfall for 2-year design return period was calculated using Gumbel Extreme Value frequency distribution. The catchment area was demarcated using Google Earth and topography. Time of concentration (Tc) $=10 \mathrm{~min}$ was used for the design rainfall intensity. The composite $\mathrm{CN}$ was calculated based on land use type and hydrological soil group D. The SCS-CN is based on a water balance equation as given below. 
Table 1. Critical ponding roads with ponding depth and inundation area.

\begin{tabular}{|c|c|c|c|c|c|}
\hline Ponding Area Name & $\begin{array}{c}\text { Ponding } \\
\text { Depth (inch) }\end{array}$ & $\begin{array}{l}\text { Inundation } \\
\text { Area (ac) }\end{array}$ & Ponding Area Name & $\begin{array}{c}\text { Ponding } \\
\text { Depth (inch) }\end{array}$ & $\begin{array}{l}\text { Inundation } \\
\text { Area (ac) }\end{array}$ \\
\hline $\begin{array}{c}\text { Near Total Petrol Pump Bhala } \\
\text { Chowk }\end{array}$ & 4 & 29.6 & $\begin{array}{l}\text { Near Shrine of Shah } \\
\text { Jamal }\end{array}$ & 3 & 29.5 \\
\hline Doongi Ground Ghazali Rd & 7 & 20 & $\begin{array}{l}\text { Fortress Stadium } \\
\quad \text { Circular Rd }\end{array}$ & 12 & 8.3 \\
\hline Outside Bhati Gate Ravi Rd & 9 & 18.8 & $\begin{array}{l}\text { Academy Rd, Railway } \\
\text { officers colony }\end{array}$ & 6 & 6.7 \\
\hline Laari Adda, GT Rd & 6 & 20.3 & Lawrence Road & 9 & 3 \\
\hline $\begin{array}{l}\text { Kachu Pura Near Kachu Pura } \\
\text { Drain Misri Shah }\end{array}$ & 8 & 9.2 & Queen's Road & 10 & 7.1 \\
\hline $\begin{array}{c}\text { Garhi Shahu Police Station, } \\
\text { Allama Iqbal Rd }\end{array}$ & 3 & 25.1 & Lake Road Drain & 6 & 5.5 \\
\hline $\begin{array}{l}\text { Chowk Nakhuda Wasanpura } \\
\text { Lahore }\end{array}$ & 9 & 21 & Mazang Adda & 8 & 18.2 \\
\hline Bagh Pura Gullistan Rd & 3 & 25.6 & Abid Market & 8 & 24.5 \\
\hline $\begin{array}{c}\text { Shalamar Girls College } \\
\text { Baghbanpura }\end{array}$ & 3 & 36.7 & Waris Rd & 6 & 11.6 \\
\hline Gaddafi Stadium & 6 & 5.1 & Chauburji & 4 & 11.6 \\
\hline Fruit Market & 6 & 10.8 & Hussain Chowk & 6 & 3.7 \\
\hline Railway Drain Aziz Road & 8 & 16.3 & Firdous Market & 8 & 13.2 \\
\hline $\begin{array}{l}\text { Angoori Shadi Hall Link } \\
\text { Shalamar Rd }\end{array}$ & 3 & 13.5 & $\begin{array}{l}\text { Sheranwala Gate } \\
\text { Circular Rd }\end{array}$ & 4 & 20.7 \\
\hline Railway Colony & 3 & 4 & Vegetable \& Fruit Market & 3 & 12 \\
\hline Sunny View Complex Kashmir Rd & 6 & 8.8 & Timber Market Rd & 6 & 15.9 \\
\hline Faletti's Hotel Backside & 12 & 2.1 & $\begin{array}{l}\text { Rasool Park Shama Rd } \\
\text { New Muzang Lhr }\end{array}$ & 3 & 11.8 \\
\hline Govt Islamia College Coper Rd & 10 & 6.8 & $\begin{array}{l}\text { Near Bibi Pak Daman } \\
\text { Allama Iqbal Rd }\end{array}$ & 6 & 17.8 \\
\hline $\begin{array}{l}\text { Dyal Singh College Lakshmi } \\
\text { Chowk }\end{array}$ & 36 & 8.7 & GPO Backside & 3 & 8 \\
\hline Islamia College Railway Rd & 3 & 22.1 & Karim Park & 4 & 13.4 \\
\hline Haji Camp Empress Rd & 10 & 4.7 & Hall Road & 10 & 4.3 \\
\hline $\begin{array}{l}\text { Muslim League High School } \\
\text { Empress Rd }\end{array}$ & 10 & 10.4 & Eik Moria Do Moria Pul & 9 & 13.5 \\
\hline Barkat Market & 9 & 7.8 & & & \\
\hline \multicolumn{6}{|c|}{$\begin{array}{c}I_{a}=0.2 S, \\
S=\frac{1000}{C N}-10, \\
Q=\frac{(P-0.2 S)^{2}}{(P+0.8 S)}\end{array}$} \\
\hline
\end{tabular}

where; $Q=$ runoff (inch); $P=24 \mathrm{~h}$ rainfall (inch); $S=$ potential maximum retention after runoff begins (inch); $I a=$ initial abstraction before runoff begins (inch).

The total number of required recharge wells to clean the ponding volume was calculated based on runoff volume collected at the ponding site and recharging rate of recharge wells. After prerequisite measures, two underground recharge wells along with silt trappers were constructed. The salient features of underground storage chamber and recharge well are given below.

1. Size of chamber: length (outer) $=9 \mathrm{ft}$; width (outer) $=6 \mathrm{ft}$; depth $=6-8 \mathrm{ft}$.

2. Size of silt trapper: length (outer) $=6 \mathrm{ft}$; width (outer) $=6 \mathrm{ft}$; depth $=6 \mathrm{ft}$.

3. R.C.C slabs at top of chamber $=3$ No's; size: length $=3 \mathrm{ft}$; width $=6 \mathrm{ft}$; depth $=6$ inch; concrete composition (1:2:4). 
4. R.C.C. slabs at top of silt trappers with same concrete composition; size: length $=3 \mathrm{ft}$; width $=6$ $\mathrm{ft}$; depth $=4$ inch.

5. Reinforced cement concrete walls.

6. Material at the bottom of chamber: the $1 \mathrm{ft}$ thick fine gravel layer is covered with a $1 \mathrm{ft}$ thick coarse gravel layer. The $2 \mathrm{ft}$ thick uppermost boulder layer acts as rapid filter media.

7. The foundation of chamber and silt trapper is started on the 6-inch-thick P.C.C (1:6:12) layer.

8. A 12-inch diameter perforated fiberglass pipe with $1.5 \mathrm{~mm}$ slots into underground sandy strata up to $5 \mathrm{ft}$ above water table.

9. The rainwater runoff is directed toward silt trappers via open drains where it is required, and silt trappers are connected with 6-inch diameter pipes with a recharging chamber.

10. The minimum distance of $100 \mathrm{~m}$ between two wells is recommended and wells should be $100 \mathrm{ft}$ away from the buildings; if not suitable then use $50 \mathrm{ft}$ deep blind pipe in the borehole.

\section{Results and Discussion}

\subsection{Rainwater Harvesting Potential}

During the survey, along with ponding depth of critical ponding sites, the ponding areas were also demarcated. Using ponding depth ( $\mathrm{ft}$ ) and ponding area (ac), the RWH volume was calculated in ac-ft at each critical location as shown in Figure 6. From Dyal Singh College Lakshmi Chowk, up to 26 ac-ft volume of runoff can be harvested, which is maximum from all ponding sites. It was calculated that almost 303.5 ac-ft volume of runoff from 43 critical ponding roads can be harvested. These sites have accumulated ponding depth of $25.6 \mathrm{ft}$, respectively. If considering $50 \%$ drainage factor and $20 \%$ losses along with constraints of site suitability for $\mathrm{RWH}$, it was analyzed that still there is $30 \%$ volume of rainwater runoff that can be harvested and used for recharge of Lahore aquifer. With that ratio of recharge, the groundwater level can rise to $3.54 \mathrm{ft}$ after every monsoon period, which is a key to groundwater sustainability in Lahore city.

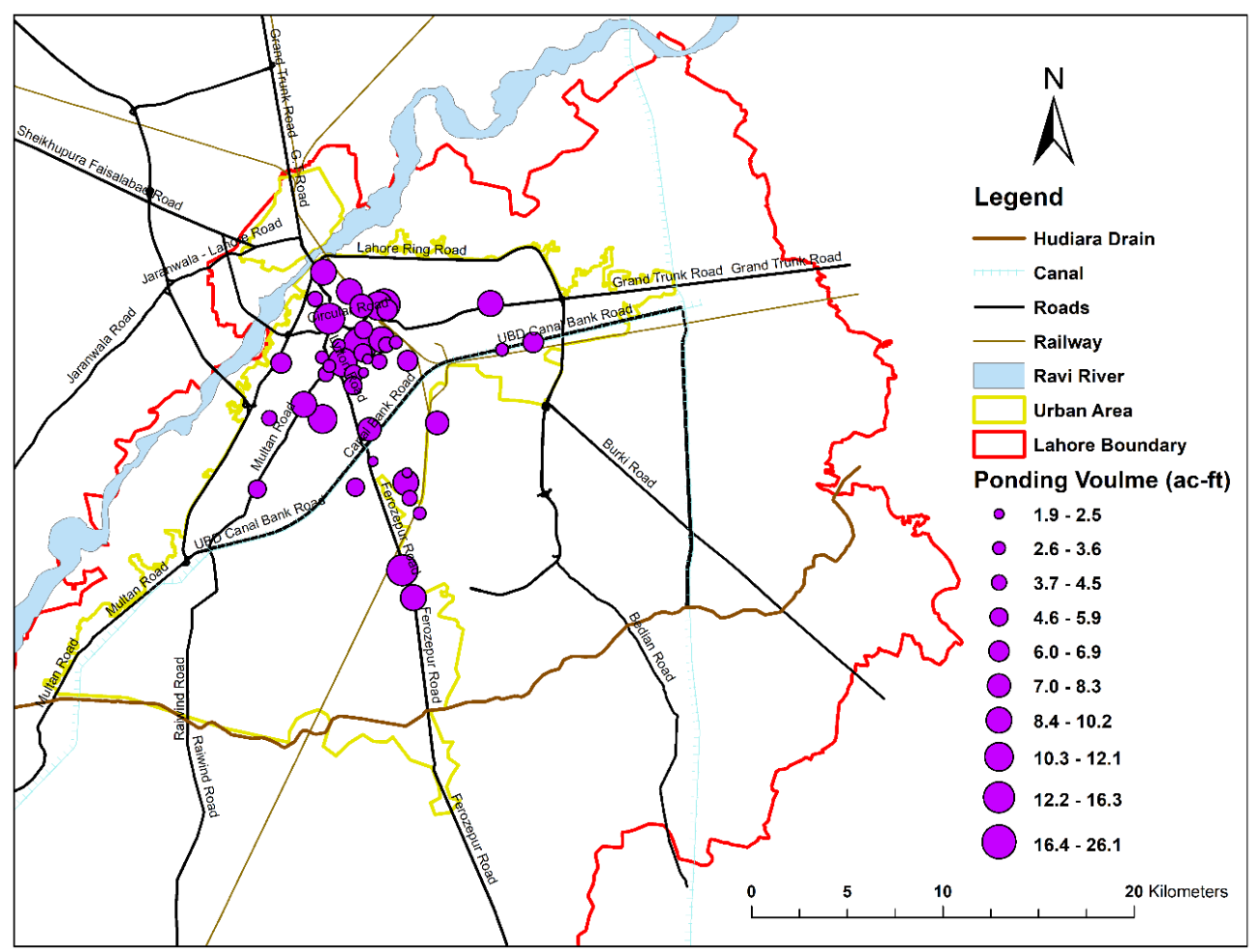

Figure 6. Rainwater harvesting potential from road runoff in the urban area of Lahore. 


\subsection{Rainwater Harvesting Utilization for Artificial Recharge of Groundwater}

The rainwater runoff from roads collected in the ponding sites was used for artificial recharge of groundwater using recharge wells. For this purpose, a case study was performed in Gaddafi Stadium ponding area. This site was selected because of site suitability for construction of a recharge well, and also one of the priority sites under poundage according to WASA and LDA Lahore. Pre-harvesting and post-harvesting measures were kept in consideration for performing this case study. Pre-harvesting measures were comprised of rainwater quality analysis and rainwater runoff estimation for mitigation of inundation while post-harvesting measures were related to the performance evaluation of recharge wells based on recharge rate and water quality analysis of recharged water.

\subsubsection{Analysis of Groundwater Mass Balance of Lahore City}

The mass balance approach was utilized to determine the change in groundwater level due to recharge and discharge from the year 2003 to 2014. The average annual difference between recharge $(2016 \mathrm{mcm})$ and discharge $(2137 \mathrm{mcm})$ is $121 \mathrm{mcm}$ (million cubic meters). This change in storage indicated that Lahore city is facing an alarming decline in the water table and the decrease rate is $0.39 \mathrm{~m}$ per annum. The continued increase in groundwater extractions has resulted in decreasing annual groundwater storage and declining of groundwater levels, as illustrated in Figure 7.

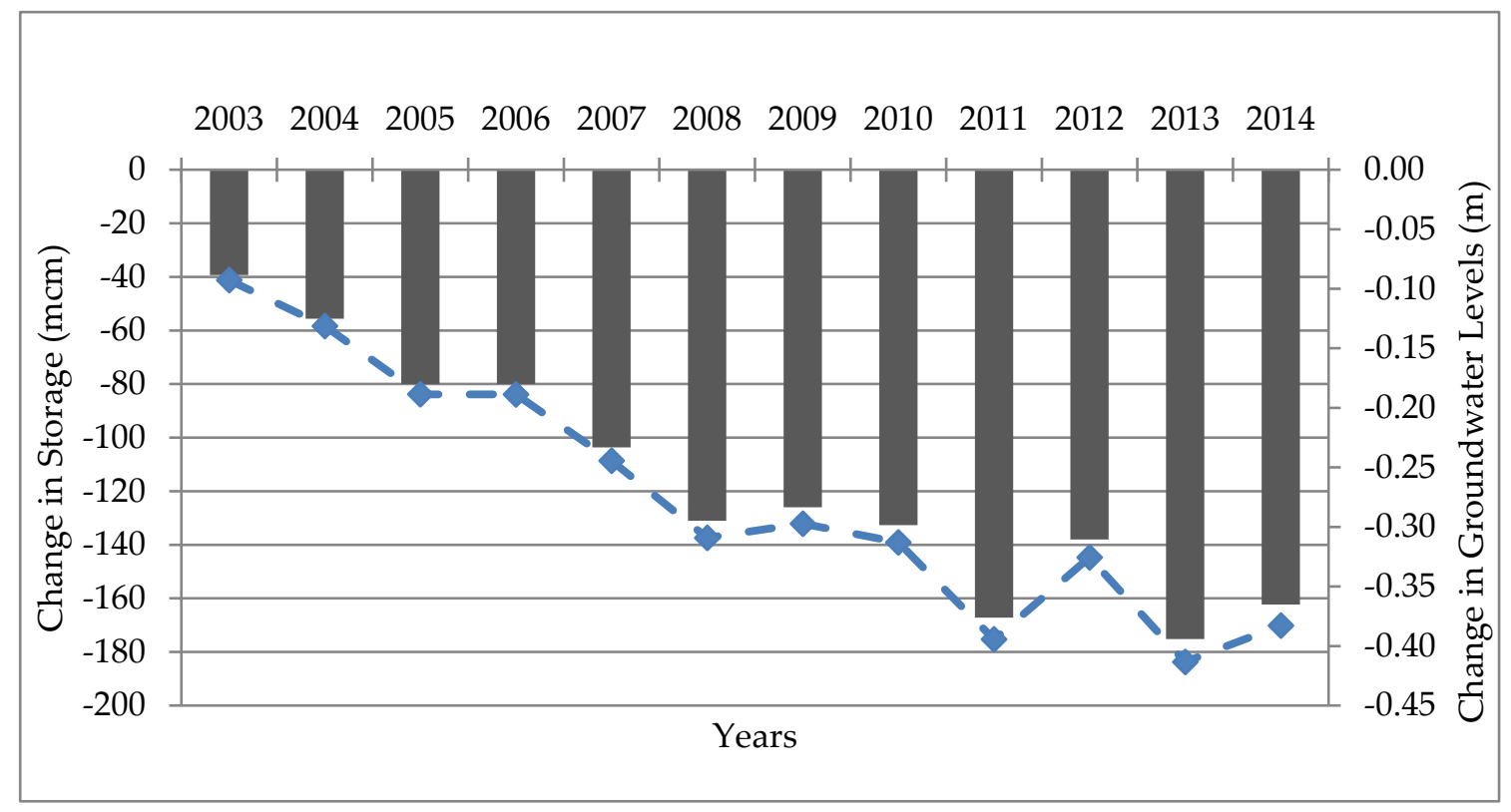

Figure 7. Change in groundwater storage and levels during 2003-2014.

\subsubsection{Drinking Water Quality Analysis}

The examination of water quality is very important to assess the water in the study area for drinking purpose. Two samples of drinking water were collected from the tube well and motor pump in the vicinity of Gaddafi Stadium Lahore. The samples were sent to PCSIR scientific laboratory for the analysis of Physico-Chemical parameters. Testing results of samples showed that all the parameters were within the permissible limit of National Environmental Quality Standards (NEQS) and World Health Organization (WHO) having zero bacterial counts as shown in Table 2. Results found that both samples of drinking water are safe for human consumption without any treatment. 
Table 2. Drinking water quality in the vicinity of Gaddafi Stadium Lahore.

\begin{tabular}{|c|c|c|c|c|}
\hline Parameter & Unit & $\begin{array}{c}\text { Sample-1 } \\
\text { (Tubewell) }\end{array}$ & $\begin{array}{c}\text { Sample-2 } \\
\text { (Motorpump) }\end{array}$ & $\begin{array}{c}\text { Limits as Per } \\
\text { NEQS }\end{array}$ \\
\hline Color & Pt-Co & $<5.0$ & $<5.0$ & $\leq 15 \mathrm{TCU}$ \\
\hline Odor & - & Odorless & Odorless & - \\
\hline Turbidity & NTU & $<0.2$ & $<0.2$ & $<5.0 \mathrm{NTU}$ \\
\hline Taste & - & Sweet & Sweet & - \\
\hline $\mathrm{pH}$ & pH Unit & 7.98 & 8.37 & $6.5-8.5$ \\
\hline Hardness total as $\mathrm{CaCO} 3$ & $\mathrm{mg} / \mathrm{L}$ & 136 & 56 & $<500$ \\
\hline Total Dissolved Solids (TDS) & $\mathrm{mg} / \mathrm{L}$ & 466 & 896 & $<1000$ \\
\hline Chlorine (Residual) & $\mathrm{mg} / \mathrm{L}$ & $<1.0$ & $<1.0$ & $0.5-1.5$ \\
\hline Nitrate (NO3) & $\mathrm{mg} / \mathrm{L}$ & 0.49 & 0.62 & $\leq 50$ \\
\hline Nitrite (NO2) & $\mathrm{mg} / \mathrm{L}$ & 0.007 & 0.005 & $\leq 3.0$ \\
\hline Chloride & $\mathrm{mg} / \mathrm{L}$ & 15.65 & 39.14 & $<250$ \\
\hline Cyanide $\mathrm{CN}$ & $\mathrm{mg} / \mathrm{L}$ & $<0.05$ & $<0.05$ & $\leq 0.05$ \\
\hline Fluoride F- & $\mathrm{mg} / \mathrm{L}$ & 0.43 & 0.41 & $\leq 1.50$ \\
\hline Arsenic (As) & $\mathrm{mg} / \mathrm{L}$ & 0.01 & 0.02 & $\leq 0.05$ \\
\hline Barium (Ba) & $\mathrm{mg} / \mathrm{L}$ & 0.04 & 0.02 & 0.70 \\
\hline Boron (B) & $\mathrm{mg} / \mathrm{L}$ & 0.11 & 0.29 & 0.30 \\
\hline Selenium (Se) & $\mathrm{mg} / \mathrm{L}$ & $<0.005$ & $<0.005$ & 0.01 \\
\hline Zinc (Zn) & $\mathrm{mg} / \mathrm{L}$ & $<1.0$ & $<1.0$ & 5 \\
\hline Cadmium (Cd) & $\mathrm{mg} / \mathrm{L}$ & $<0.002$ & $<0.002$ & 0.01 \\
\hline Chromium (Cr) & $\mathrm{mg} / \mathrm{L}$ & $<0.02$ & $<0.02$ & $\leq 0.05$ \\
\hline Copper $(\mathrm{Cu})$ & $\mathrm{mg} / \mathrm{L}$ & $<1.0$ & $<1.0$ & 2.0 \\
\hline Antimony (Sb) & $\mathrm{mg} / \mathrm{L}$ & $<0.005$ & $<0.005$ & $\leq 0.005$ \\
\hline Lead $(\mathrm{Pb})$ & $\mathrm{mg} / \mathrm{L}$ & $<0.05$ & $<0.05$ & $\leq 0.05$ \\
\hline Manganese (Mn) & $\mathrm{mg} / \mathrm{L}$ & $<0.5$ & $<0.5$ & $\leq 0.5$ \\
\hline Nickel (Ni) & $\mathrm{mg} / \mathrm{L}$ & $<0.02$ & $<0.02$ & $\leq 0.02$ \\
\hline Aluminum (Al) & $\mathrm{mg} / \mathrm{L}$ & $<0.005$ & $<0.005$ & $\leq 0.2$ \\
\hline Mercury (Hg) & $\mathrm{mg} / \mathrm{L}$ & $<0.001$ & $<0.001$ & $\leq 0.001$ \\
\hline Total Coliform & CFU/100 mL & Absent & Absent & $0 / 100 \mathrm{~mL}$ \\
\hline Fecal Coliform (Escherichia coli) & CFU/100 mL & Absent & Absent & 0/100 mL \\
\hline
\end{tabular}

\subsubsection{Rainwater Quality Analysis}

Rainwater was used for recharging of groundwater, therefore it was considered necessary to maintain its quality. As most public health problems are related to contaminated water and hygiene customs, the access to good quality water is one of the most important factors to improve people's health and to protect human health. Therefore, water sources must be of good quality and protected from contamination. The rainwater samples were collected by a person who had proper training and adequate experience. The collection of rainwater samples was done from the inlet of the pit at 30 min for rainfall at Gaddafi Stadium ponding site and these samples were sent to PCSIR and PCRWR Scientific Laboratories for the Physico-Aesthetic Chemical and Microbiological analysis of rainwater samples. The test results of these laboratories are given below in Table 3. 
Table 3. Rainwater quality of collected samples at Gaddafi Stadium ponding site.

\begin{tabular}{|c|c|c|c|}
\hline Sr. No & Water Quality Parameter & Permissible Limits & Results \\
\hline 1 & Chloride (mg/L) & 250 (WHO) & 24 \\
\hline 2 & Sulfate $(\mathrm{mg} / \mathrm{L})$ & $250(\mathrm{WHO})$ & 07 \\
\hline 3 & TDS (mg/L) & $1000(\mathrm{WHO})$ & 78 \\
\hline 4 & $\begin{array}{l}\text { Biological Oxygen Demand (BOD) } \\
(\mathrm{mg} / \mathrm{L})\end{array}$ & 150 (NEQS) & 78 \\
\hline 5 & Copper $(\mathrm{mg} / \mathrm{L})$ & $2(\mathrm{WHO})$ & 0.13 \\
\hline 6 & Arsenic $(\mu \mathrm{g} / \mathrm{L})$ & $10(\mathrm{WHO})$ & 5.65 \\
\hline 7 & Fluoride $(\mathrm{mg} / \mathrm{L})$ & $1.5(\mathrm{WHO})$ & 0.20 \\
\hline 8 & Total Coliform (MPN/100 mL) & 0 (WHO) & 96 \\
\hline 9 & Fecal Coliform (E. Coli) (MPN/100 mL) & $0(\mathrm{WHO})$ & 21 \\
\hline 10 & Lead (ppm) & $0.05 \mathrm{mg} / \mathrm{L}(\mathrm{WHO})$ & Not detected \\
\hline 11 & Cadmium (ppm) & $0.01 \mathrm{mg} / \mathrm{L}(\mathrm{WHO})$ & Not detected \\
\hline 12 & Copper (ppm) & $2 \mathrm{mg} / \mathrm{L}(\mathrm{WHO})$ & Not detected \\
\hline 13 & $\begin{array}{c}\text { Pesticides residues as } \\
\text { Chlorpyrifos (ppm) } \\
\text { Bifenthrin (ppm) }\end{array}$ & & Not detected \\
\hline 14 & Sulfides (ppm) & & Not detected \\
\hline
\end{tabular}

The testing results of laboratories samples showed that all the parameters are within the permissible limit against different standards but the highlighted parameters (Total Coliform and Fecal Coliform (Escherichia. Coli)) are under the prescribed standard. The presence of coliform may be due to incorporation of air-borne microbes in the rainwater as it passes through the atmosphere and buildup of sediments and particulates as well as other elements from the catchment materials and other environmental factors which enhance the growth of microbes. Rainwater is a fresh source of water used for recharging groundwater, hence quality standards must be maintained. Rainwater unfortunately often does not meet the WHO water quality guidelines. This does not mean that the water is unsafe to use. It can be made for favorable use by adopting quality controls measures. To make the water for safe use and recharge in groundwater, chlorination and filtration processes may be adopted in the design of recharge wells. Moreover, the installation of bio-retention basins could be recommended to prevent contamination of the runoff from heavy metals.

When stormwater runoff is used in recharging systems, the vadose zone and in some cases the aquifer act as a natural filter that typically reduces the concentration of various pollutants due to physical, chemical, and microbiological processes. Suspended solids are filtered out; biodegradable organic compounds are decomposed; microorganisms are adsorbed, strained out, or die because of competition with other soil microorganisms; nitrogen concentrations are reduced by denitrification; synthetic organic compounds are adsorbed and/or biodegraded; and phosphorous, fluoride, and heavy metals are adsorbed, precipitated, or otherwise immobilized. Thus, soil-aquifer treatment can be an important step in the treatment of recharged stormwater. Most soil-aquifer treatment processes take place in the upper part of the vadose zone where soils generally are finer and have a greater organic matter content than in the aquifer.

\subsubsection{Rainwater Runoff Estimation for Mitigation of Inundation and Design of Recharge Wells}

Rainwater runoff estimation is the key point for implementation of a RWH recharge well. This was done by collecting and analyzing of the following data. 
i. Collection of annual maximum daily rainfall data of Lahore for performing frequency analysis and estimating daily maximum rainfall of desired return periods.

ii. Estimation of the catchment area of ponding site.

iii. Peak runoff estimation for 2-year rainfall frequency.

The annual maximum daily rainfall data of Lahore spanning over 58 years from 1957 to 2014 was collected for estimation of rainfall-runoff (Figure 8). The rainfall data showed that the daily maximum rainfall ranges from 29 to $211 \mathrm{~mm}$ with an average value of $80 \mathrm{~mm}$. This data was used for estimating the runoff peaks resulting from daily rainfall of desired frequency.

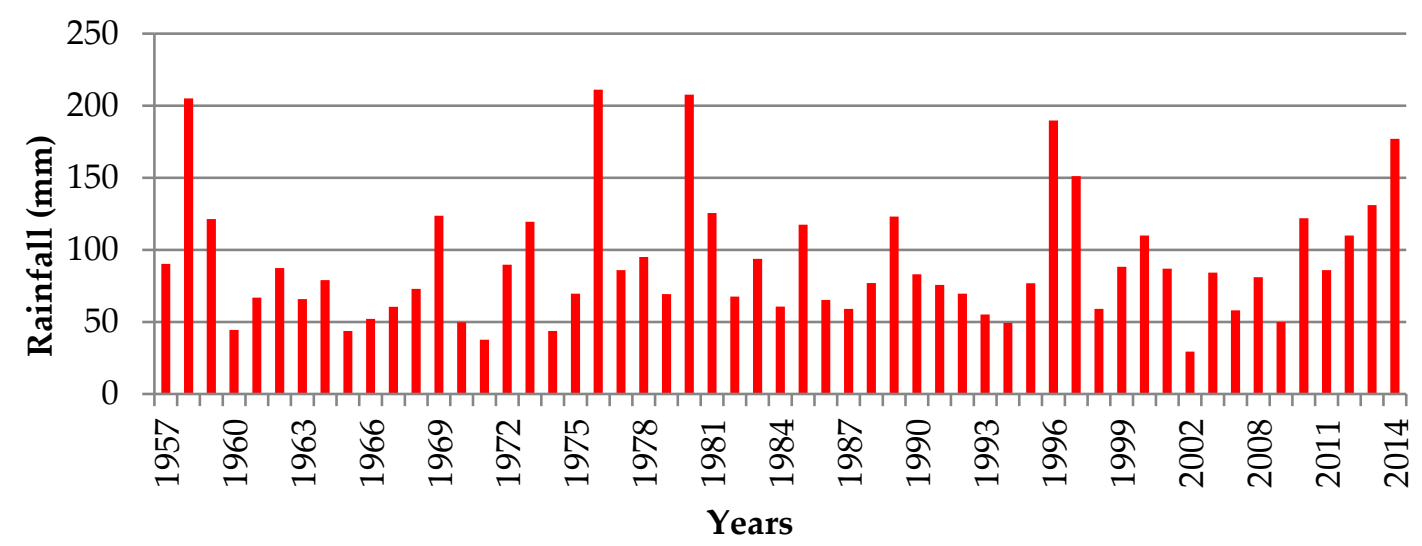

Figure 8. The annual maximum daily rainfall hyetograph of Lahore city.

Frequency analysis of annual maximum daily rainfall data of Lahore was carried out for estimation of 2-year, 5-year, and 10-year frequency rainfall by using Gumbel Extreme Value distribution. The results of frequency analysis are given below.

i. $\quad$ 2-year maximum daily rainfall $=83 \mathrm{~mm}$ (3.3 inches).

ii. $\quad 5$-year maximum daily rainfall $=103 \mathrm{~mm}$ (4.1 inches).

iii. $\quad 10$-year maximum daily rainfall $=149 \mathrm{~mm}$ (5.86 inches).

The catchment area of Gaddafi Stadium ponding site was demarcated using Google Earth as shown in Figure 9. The total catchment area is $0.022 \mathrm{~km}^{2}(5.43 \mathrm{ac})$ and consists of main Gaddafi Stadium road and Hafeez Kardar road.

Peak runoff estimation was done using the US-SCS Curve Number Method. The storm rainfall of 2-year frequency was used as input and characteristics of the catchment area such as composite curve number based on landcover $(\mathrm{CN}=74)$ and the soil hydrological group $\mathrm{D}$ were selected for runoff estimation. The time of concentration $(\mathrm{Tc})=10 \mathrm{~min}$ was used to find the intensity of rainfall $(3.75 \mathrm{in} / \mathrm{h})$ for the 2-year design return period from intensity duration frequency (IDF) curve as shown in Figure 10. 


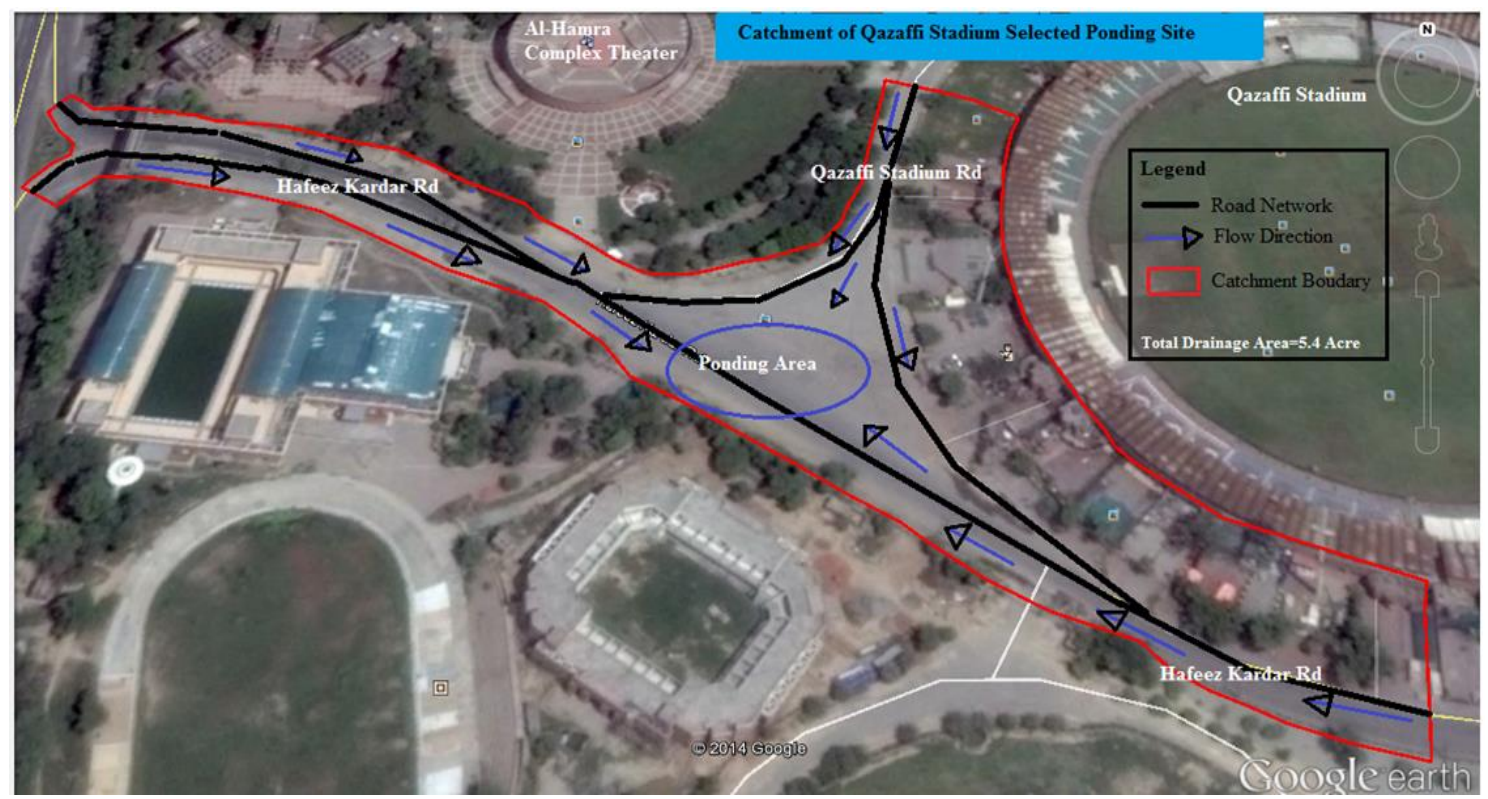

Figure 9. Demarcation of catchment area of Gaddafi Stadium ponding site.

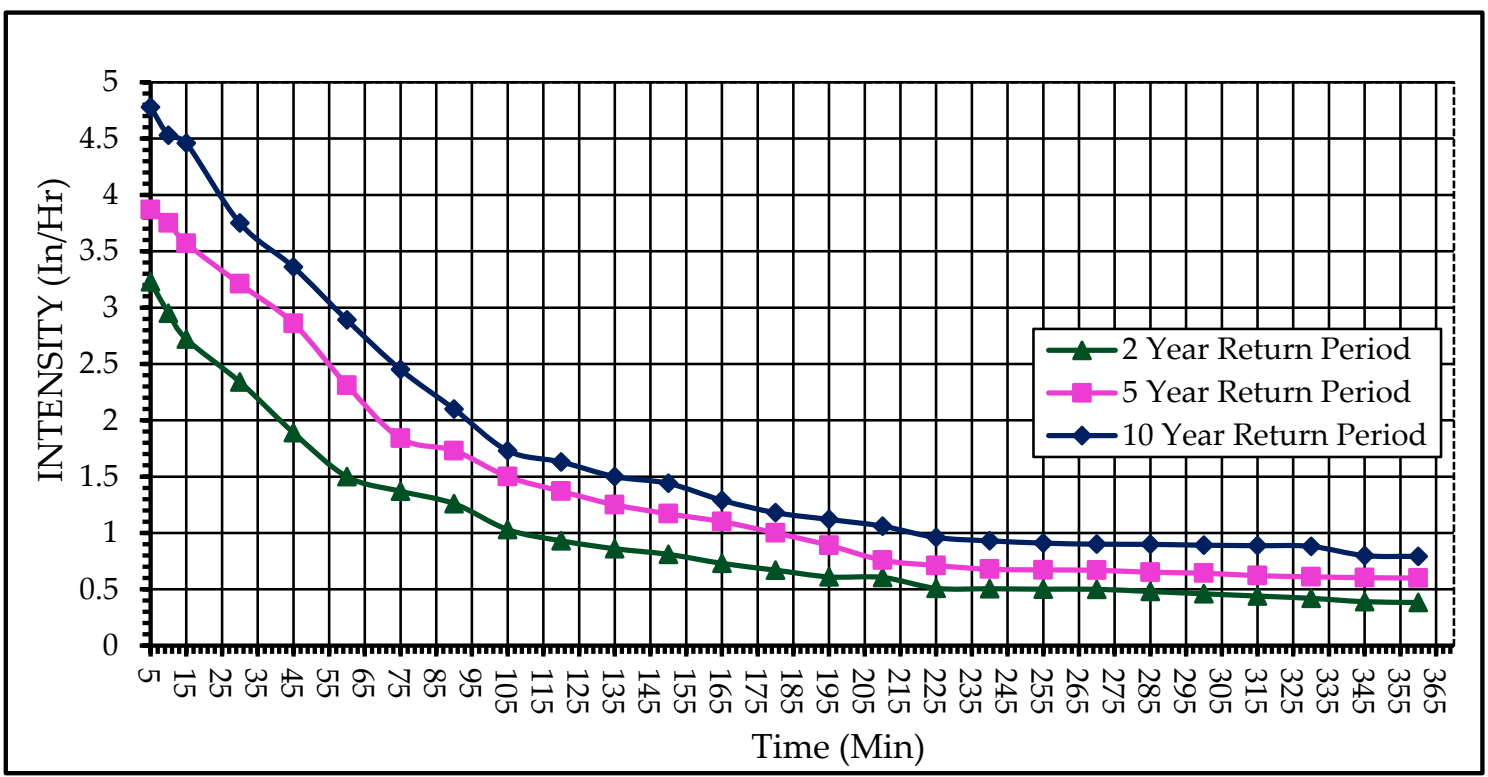

Figure 10. Intensity duration frequency (IDF) for Lahore city.

The total runoff volume collected at the ponding site is $616.2 \mathrm{~m}^{3}(0.5 \mathrm{ac}-\mathrm{ft})$. Considering the drainage factor of 0.5 with other losses, the runoff volume that could be harvested using a recharge well is 0.25 ac-ft.

\subsubsection{Estimation of Required Recharge Wells and Ponding Area Clearance Time}

Recharging flow (Qr) by constant head recharge in bore well is calculated by using the following equation:

$$
Q_{r}=2.75 \times d \times H \times K,
$$

where,

$d=$ diameter of recharge well $(\mathrm{m})=0.457 \mathrm{~m}$;

$H=$ depth of pervious sand strata from ground level $=20 \mathrm{~m}$; 
$K=$ Coefficient of permeability $=28 \mathrm{~m} / \mathrm{d}=0.000324074 \mathrm{~m} / \mathrm{s}$.

Based on Equation (4) and values of parameters the recharging capacity of the well was estimated as $29.32 \mathrm{~m}^{3} / \mathrm{h}$.

The hydraulic conductivity value was taken from Lahore Water Supply, Sewerage and Drainage Master Plan-2040 (by WASA and LDA Lahore) as shown in Figure 11.

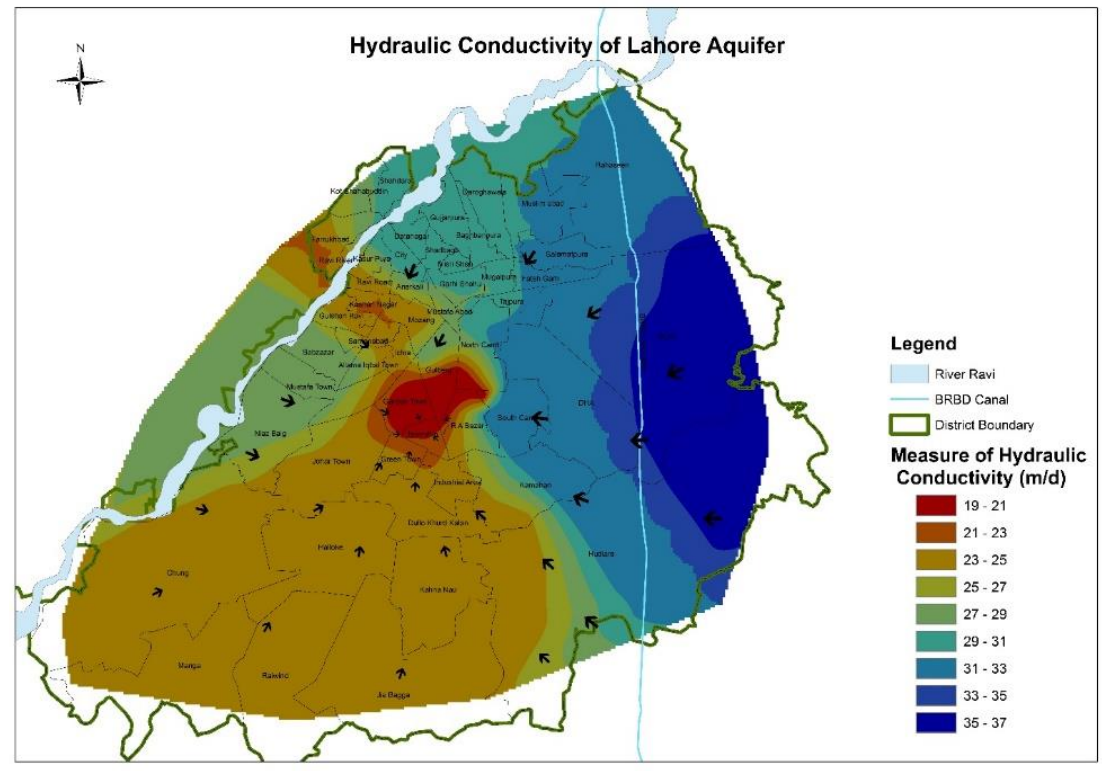

Figure 11. Hydraulic conductivity map of Lahore aquifer.

The ponding area runoff clearance time was calculated based on the flow rate formula.

$$
Q_{r}=\frac{V}{T},
$$

where, $Q r=$ Recharge rate $\left(\mathrm{m}^{3} / \mathrm{h}\right) ; V=$ Runoff volume $\left(\mathrm{m}^{3}\right)$, and $T=$ Clearance time $(\mathrm{h})$.

Based on recharge rate and runoff volume of 2-year frequency, the calculated clearance time and No. of required wells for 6-h detention period are given in Table 4.

Table 4. Calculation of ponding area clearance time and required No. of wells at Gaddafi Stadium

\begin{tabular}{ccccccc}
\hline Sr. No & $\begin{array}{c}\text { Ponding } \\
\text { Location }\end{array}$ & $\begin{array}{c}\text { Catchment } \\
\text { Areas } \\
\text { (acres) }\end{array}$ & $\begin{array}{c}\text { Runoff } \\
\text { Volume } \\
\left.\mathbf{( m}^{3}\right)\end{array}$ & $\begin{array}{c}\text { Recharging } \\
\text { Capacity of } \\
\text { Well }\left(\mathbf{m}^{3} / \mathbf{h}\right)\end{array}$ & $\begin{array}{c}\text { Ponding Area Clearance } \\
\text { Time with a Drainage } \\
\text { Factor } \mathbf{0 . 5}(\mathbf{h})\end{array}$ & $\begin{array}{c}\text { No. of } \\
\text { Required } \\
\text { Wells }\end{array}$ \\
\hline 1 & $\begin{array}{c}\text { Gaddafi } \\
\text { Stadium }\end{array}$ & 5.43 & 616.2 & 29.32 & 10.5 & 2 \\
\hline
\end{tabular}

\subsubsection{Design and Construction of Filter Media}

An experimental setup was installed to check out the efficiency of media filter used in the construction of recharge wells for infiltration purposes, as shown in Figure 12. The filter media consist of a 12-inch layer of boulders (size range $=15-25 \mathrm{~mm}$ ), and a 6-inch layer of coarse and fine aggregate having size ranges of $8-12 \mathrm{~mm}$ and $6-8 \mathrm{~mm}$, respectively. 


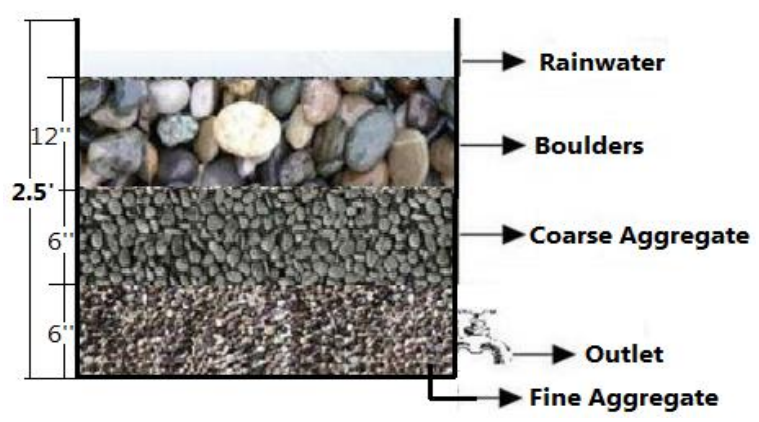

Figure 12. Filter media design for the recharge well infiltration mechanism.

The collected rainwater samples before and after passing the filter media were analyzed based on turbidity, $\mathrm{pH}$, Total Suspended Solids (TSS), calcium, magnesium, and total hardness. The efficiency of filter media was assessed in terms of percent removal of the aforementioned parameter before and after the filter media passing. The removal efficiency of media filter has the following range: $90 \%-95 \%$ (TSS), 40\%-52\% (Calcium), 40\%-50\% (Magnesium), 35\%-40\% (Alkalinity), 45\% (Total Hardness), as shown in Figure 13. It was observed that $\mathrm{pH}$ value increased after filtration which might be due to the dissolution of anions from the packing materials.

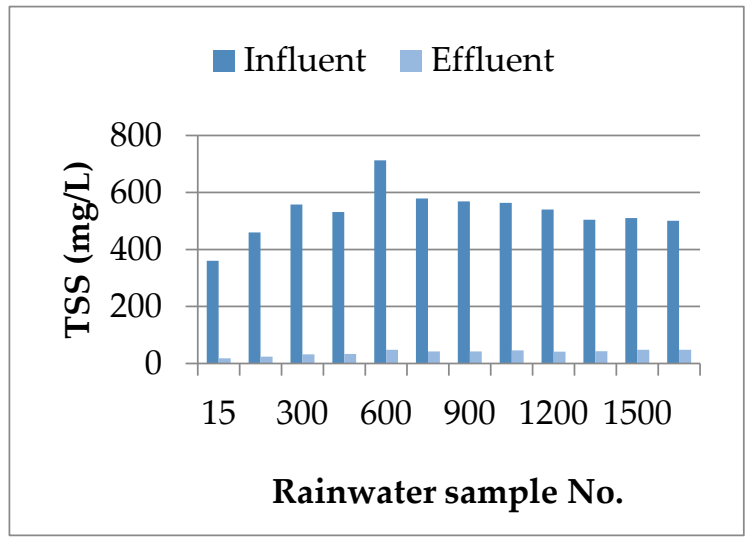

(a)

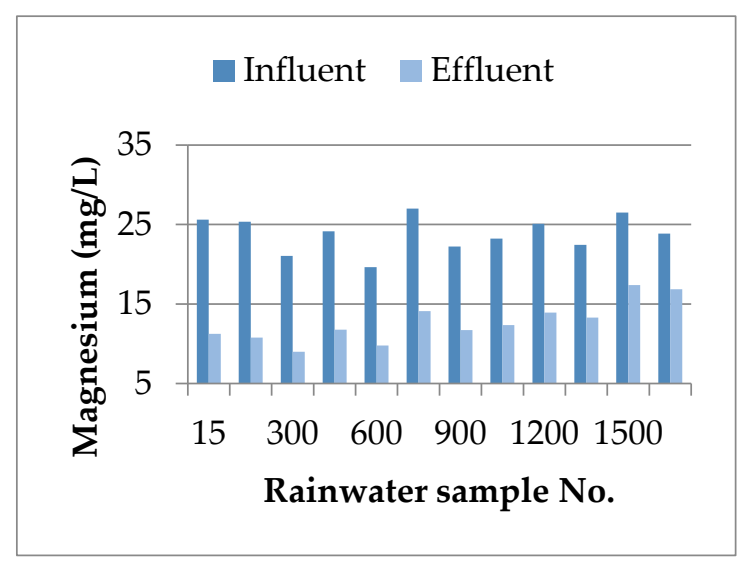

(c)

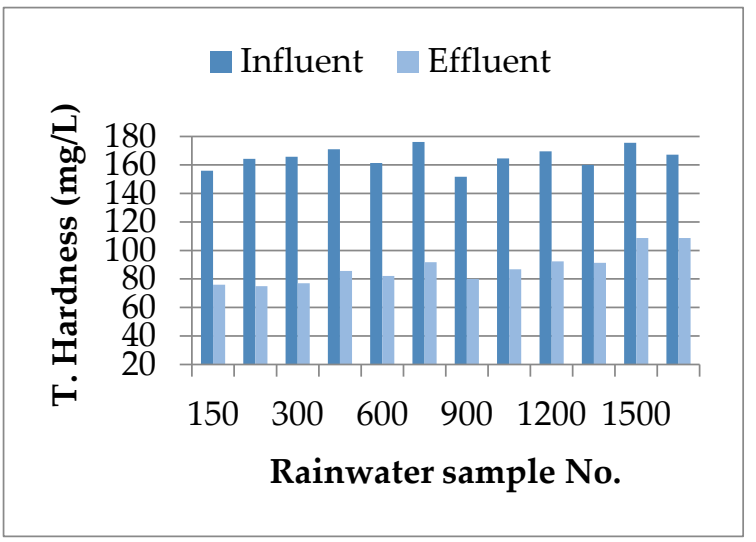

(b)

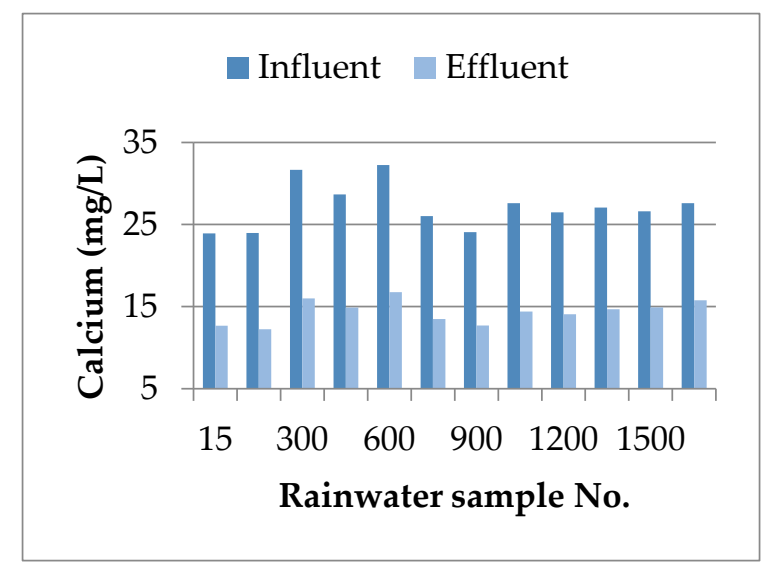

(d)

Figure 13. Cont. 


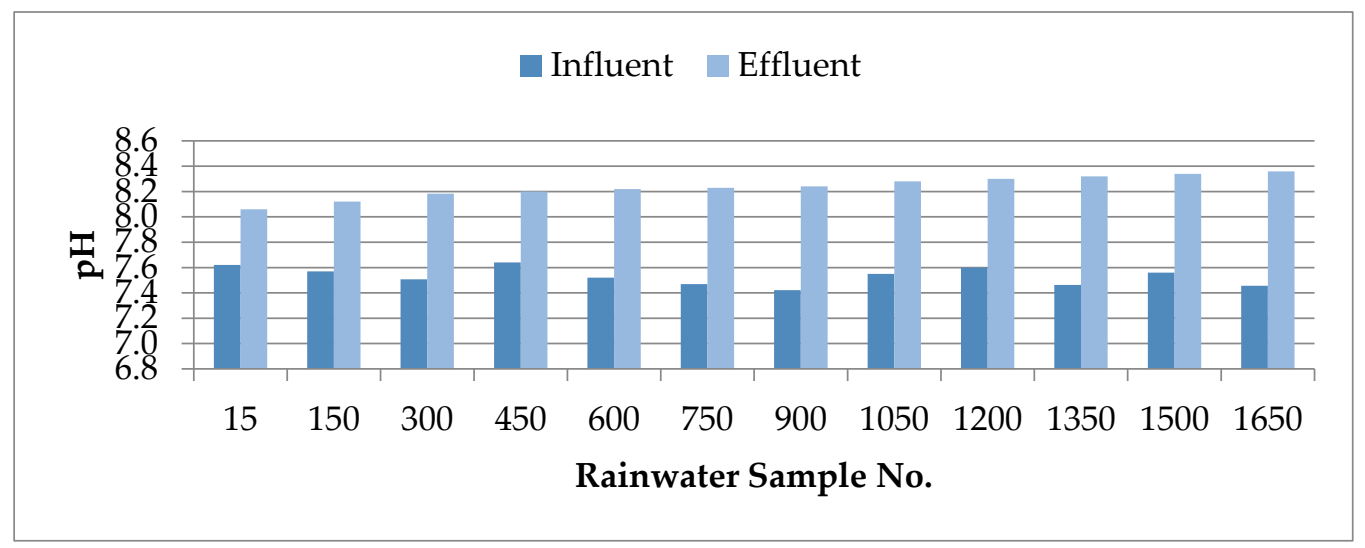

(e)

Figure 13. The efficiency of experimental filter media used in recharge well. The comparison of (a) TSS; (b) Total Hardness; (c) Magnesium; (d) Calcium; and (e) $\mathrm{pH}$ parameters before and after passing the filter media.

\subsubsection{Design and Construction of Recharge Well}

The designing of recharge well was done based on three key points i.e., the design should be according to location and available space, the drawdown of standing water into the groundwater table should be as rapid as possible. Moreover, the involvement of impurities in the recharging of groundwater needs to be minimized. The design approach works on the principle that surface water runoff flows into an underground tank that is $6 \mathrm{ft}$ deep and $9 \mathrm{ft}$ wide. This tank is equipped with a 2 $\mathrm{ft}$ deep coarse filter mechanism to avoid debris, clay, or any other choking material. The horizontal filtration mechanism provides silt and clay free water to recharge the groundwater. The water will get drained into groundwater due to head difference. In this way, the inflow rate will approximately be equal to recharge rate. The typical design with all specifications is shown in Figure 14.

This design is used in that location where the flow of traffic is minimum and there is no obstruction to any flow of life. The advantages of this design are that the groundwater recharge rate is high as water flowing in from the surface and drains down into the groundwater rapidly. Hence, the inflow rate will approximately be equal to recharge rate and the design structure is simple to construct and easy to maintain. While, the disadvantages of this design are that the heavy metals will face little hindrance in making their way to the underground water storage, resulting in contamination of water. Heavy metals like arsenic (III and V), lead, mercury, and cadmium are injurious to health and the filtration material requires periodic cleaning to keep the filtration process efficient.

The suitability of this design approach for recharging of groundwater table became more favorable by adopting the following water quality measures in design. (i) The length of borehole pipe was kept 5 $\mathrm{ft}$ above the water table because the soil is a natural filter material which purifies the rainwater before entering into the groundwater. (ii) The silt trapper structures known as settlement chambers were provided where suitable and necessary with the recharge chamber. These settlement chambers were used to remove silt and other floating impurities from rainwater. Additionally, in the case of excess rainfall, the recharging rate of bore wells may not match with the rate of rainfall. In such situations, these chambers hold the excess amount of water till it is soaked up by the recharge structure. Thus, the settlement chamber acts as a buffer in the system.

\subsubsection{Cost Estimation and Construction of Recharge Wells}

Two recharge wells were constructed according to the above-mentioned design for rainwater harvesting in Gaddafi Stadium by LDA Lahore under the rainwater harvesting project. The layout view of recharge wells is shown in Figure 15. 


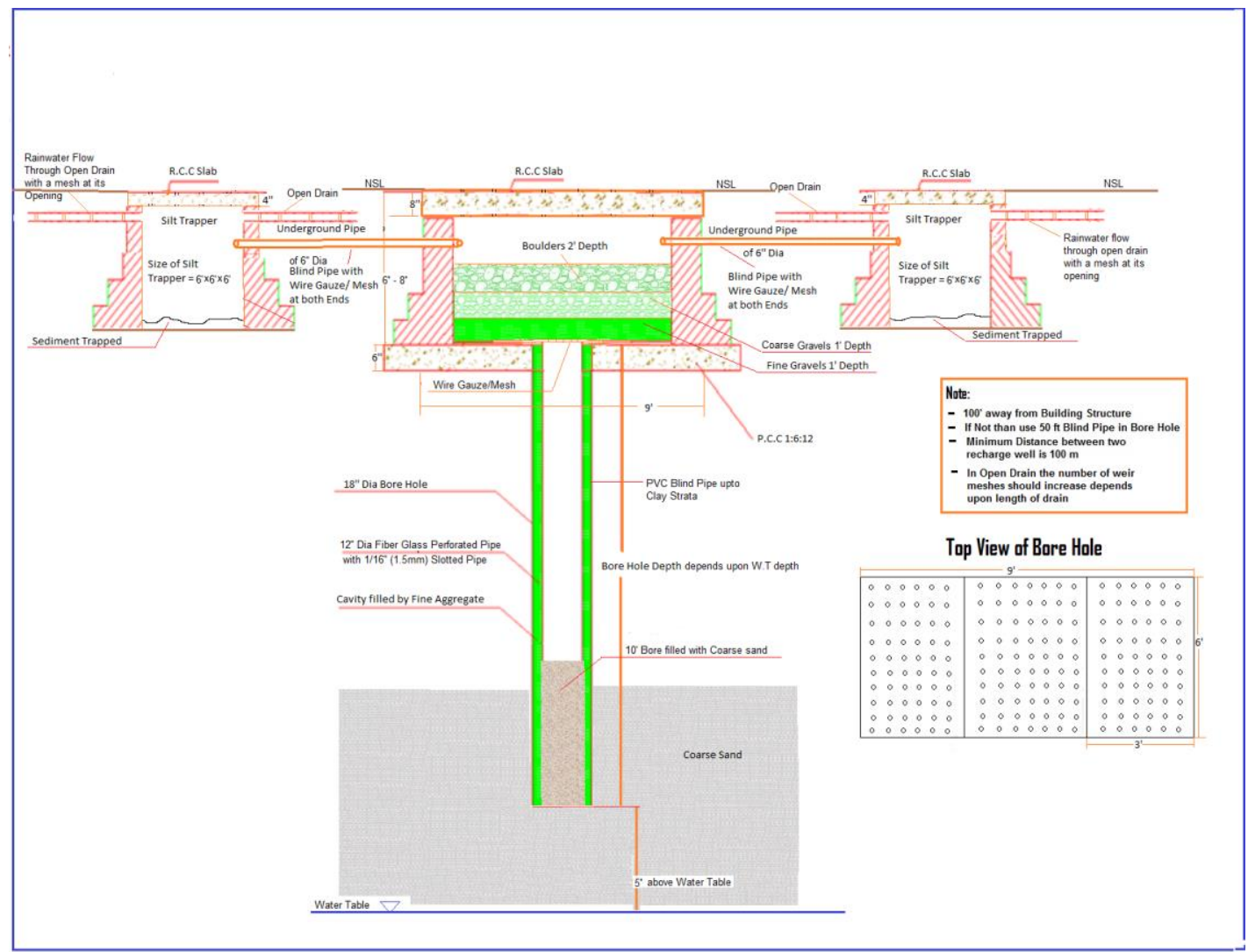

Figure 14. Typical design of a recharge well used for rainwater harvesting (RWH) in Gaddafi Stadium.

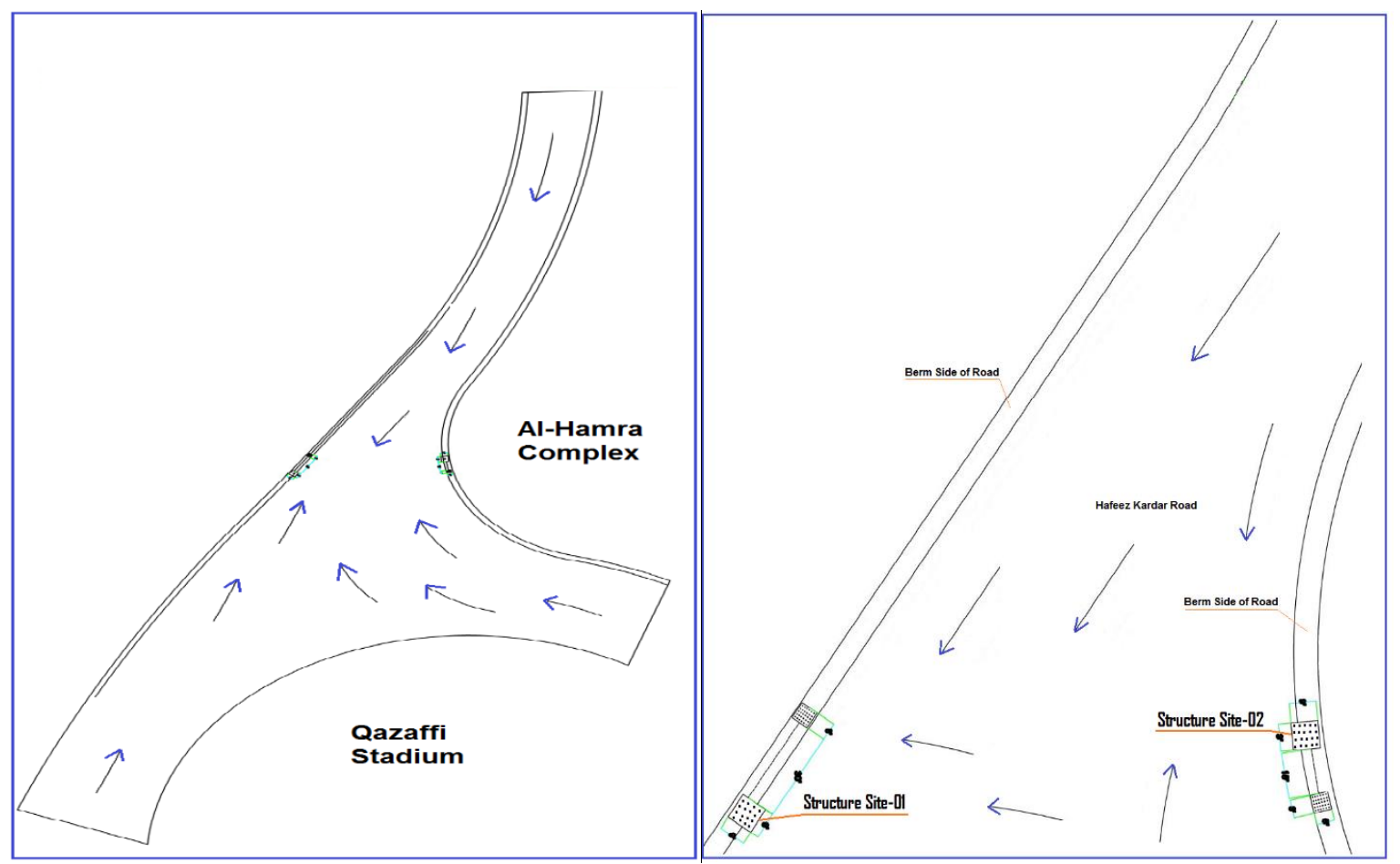

Figure 15. Layout view of recharge well construction site.

The cost estimation and analysis of a single recharge well was performed to put more perspective into the potential viability of implementing such systems on a city-wide scale. The cost of a typical 
underground storage chamber/recharge well was estimated as Pakistani Rupees (PKR) 0.738 million. The cost breakthrough of elements include in RWH structure are given below (Table 5).

Table 5. Cost of civil work and elements include in RWH structure.

\begin{tabular}{ccc}
\hline Sr. No & Work & Cost (PKR) \\
\hline 1 & $\begin{array}{c}\text { Excavation including dag-belling, dressing, refilling around structure with } \\
\text { excavated earth, watering, ramming, re-handling, and transportation } \\
\text { Direct Rotary/Reverse Rotary drilling of in all types of soil except shingle, }\end{array}$ & $20,000.00$ \\
gravel, and rock & $50,000.00$ \\
3 & Cement concrete plain including placing, compacting, finishing, and curing. & $10,000.00$ \\
4 & Reinforced Cement Concrete (RCC) (1:2:4), main slabs & $20,000.00$ \\
5 & Fabrication of mild steel, deformed bars grade-40 & $30,000.00$ \\
6 & Cement plaster 1:3 & 5000.00 \\
7 & Suppling and filling sand & 5000.00 \\
8 & Brick masonry (1:3) other than building & $30,000.00$ \\
9 & Installing fiber glass blank pipe in the borehole including joining with the & $165,000.00$ \\
10 & fiber glass blank pipe/strainer & $185,000.00$ \\
11 & Installing fiber glass strainer pipe in the borehole including joining & 8000.00 \\
12 & Providing and laying crush stone (3/4" to 1") & 5000.00 \\
13 & Providing and laying coarse gravels and boulders & 2000.00 \\
14 & Fixing wire mesh & 5000.00 \\
& Miscellaneous items & $540,000.00$ \\
& Sub-total & $108,000.00$ \\
& 2\% Contingencies & $90,000.00$ \\
& Repair and maintenance cost & $738,000.00$
\end{tabular}

\subsection{Performance Evaluation of Recharge Wells (Post Harvesting)}

The performance of recharge wells was evaluated in terms of recharge rate and post-harvesting water quality. During the rainfall record event on 22 May, 2015, it was observed that after 10 min of rainfall, the water started flowing toward the recharge wells. Initially, the recharge rate was slow due to less rainfall but with time as the intensity of rainfall increased the recharge rate increased and reached its designed rate. The performance of the wells was satisfactory, and it was observed that both recharge wells cleared the ponding volume within 3 to $3.5 \mathrm{~h}$ after the rainfall stopped. On the second day after the rainfall event, the condition of recharge wells and the ponding site was investigated. It was observed that the settling chambers were covered with leaves, plastic bags, and loose materials intermixed with clay and silt. The main chambers were safe due to Reinforced Cement Concrete (RCC) slab. These observations indicated that the operation and maintenance of recharge chambers is necessary for proper infiltration of rainwater. With the passage of time, the recharge rate of recharge wells may decrease due to clogging inside the well. Therefore, development of the well by surging, jetting, or any other conventional well development technique is necessary to restore the recharge rate before every monsoon period.

After the monsoon period of year 2015, the water quality samples from both wells were collected and send to PCRWR Scientific Laboratory for the analysis of Physico-Aesthetic Chemical and Microbiological parameters. The comparative water quality results of pre- and post-harvesting are given in Table 6. 
Table 6. Pre- and post-harvesting water quality comparison of the Gaddafi Stadium ponding site.

\begin{tabular}{ccccc}
\hline Sr. No & $\begin{array}{c}\text { Water Quality } \\
\text { Parameter }\end{array}$ & $\begin{array}{c}\text { Permissible } \\
\text { Limits }\end{array}$ & Pre-Harvesting & Post-Harvesting \\
\hline 1 & Chloride $(\mathrm{mg} / \mathrm{L})$ & $250(\mathrm{WHO})$ & 24 & 5.6 \\
\hline 2 & Sulfate $(\mathrm{mg} / \mathrm{L})$ & $250(\mathrm{WHO})$ & 78 & 03 \\
\hline 3 & TDS $(\mathrm{mg} / \mathrm{L})$ & $600(\mathrm{WHO})$ & 78 & *BDL \\
\hline 4 & BOD $(\mathrm{mg} / \mathrm{L})$ & $80(\mathrm{NEQS})$ & 0.13 & 0.7 \\
\hline 5 & Copper $(\mathrm{mg} / \mathrm{L})$ & $2(\mathrm{WHO})$ & 5.65 & 0.10 \\
\hline 6 & Arsenic $(\mu \mathrm{L} / \mathrm{L})$ & $10(\mathrm{WHO})$ & $\mathbf{9 6}$ & $\mathbf{1 0}$ \\
\hline 7 & Fluoride $(\mathrm{mg} / \mathrm{L})$ & $1.5(\mathrm{WHO})$ & $\mathbf{2 1}$ & $\mathbf{3}$ \\
\hline 8 & $\begin{array}{c}\text { Total Coliform } \\
(\text { MPN/100 mL) }\end{array}$ & $0(\mathrm{WHO})$ & Not detected & Not detected \\
\hline 10 & $\begin{array}{c}\text { Fecal Coliform }(E . \text { Coli) } \\
\text { (MPN/100 mL) }\end{array}$ & $0(\mathrm{WHO})$ & Not detected & Not detected \\
\hline 11 & Lead $(\mathrm{ppm})$ & $0.05 \mathrm{mg} / \mathrm{L}(\mathrm{WHO})$ & Not detected & Not detected \\
\hline 12 & Cadmium $(\mathrm{ppm})$ & $0.01 \mathrm{mg} / \mathrm{L}(\mathrm{WHO})$ & Not detected & Not detected \\
\hline 13 & Copper $(\mathrm{ppm})$ & $2 \mathrm{mg} / \mathrm{L}(\mathrm{WHO})$ & Not detected & Not detected \\
\hline
\end{tabular}

${ }^{*} \mathrm{BDL}=$ Below Detectable Limit.

The testing results of samples showed that all the parameters are within the permissible limit against different standards but the highlighted parameters (Total Coliform and E. Coli) are under the prescribed standard. Additionally, the BOD value is under the below detectable limit which means its value is less than $5 \mathrm{ppm}$ or equal to zero after harvesting the rainwater which indicated the efficiency of the filter media. Drinking water, however, was assessed by TDS (should be less than $600 \mathrm{ppm}$ ) and coliform count indicated the presence of sewage. In such a case, the use of chlorine or other suitable material such as charcoal is recommended to shut up the signals. The filter media performance was favorable, and the percentage removal of contamination was about $25 \%-30 \%$ which gave recharging water within water quality standards.

\section{Conclusions and Recommendations}

This study covered the surface rainwater-runoff harvesting system using the recharge well technique in the ponding area of Gaddafi Stadium Lahore along with rainwater harvesting potential from roads in Lahore city. The study aimed at using rainwater for recharging the groundwater table with the help of the local recharge well technique and to avoid the mixing of rainwater in municipal sewerage. It was estimated that almost 303.5 ac-ft volume of runoff from 43 critical ponding roads could be harvested. There is a huge potential of RWH and half of the volume after $50 \%$ drainage can be recharged using recharge wells. With that ratio of recharge, the groundwater level can rise to $3.54 \mathrm{ft}$ after every monsoon period, which is a key to groundwater sustainability in Lahore city. The performance of the wells was satisfactory, and it was observed that both recharge wells cleared the ponding volume within 3 to $3.5 \mathrm{~h}$ after rainfall stopped in Gaddafi Stadium. The filter media performance was also favorable, and the percentage removal of contamination was about $25 \%-30 \%$ which gives recharging water within water quality standards except for coliform count that indicated the presence of sewage. In such a case, the use of chlorine or other suitable material is recommended to shut up 
the coliform signals. Further, grassed drains and/or small bio-retention basins are recommended to prevent contamination of the rainwater-runoff from heavy metals. These measures could be installed prior to runoff entering the groundwater chamber to assist in the treatment of heavy metals. With time, the recharge rate of recharge wells may decrease due to clogging inside the well. Therefore, development of the well by surging, jetting, or any other conventional well development technique is necessary to restore the recharge rate before every monsoon period. The regular operation and maintenance of recharge chambers is necessary for proper infiltration of rainwater. This technique is suitable for artificial recharge of groundwater and should be implemented on critical ponding sites in the urban area of Lahore for freshwater sustainable development.

Author Contributions: Conceptualization, F.H. and R.H.; Data curation, T.A.; Formal analysis, R.-S.W.; Investigation, T.A.; Methodology, F.H.; Project administration, R.H.; Supervision, R.H.; Writing-original draft, F.H.; Writing-review and editing, R.-S.W.

Funding: The funding is covered under Rainwater Harvesting Pilot Project at Gaddafi Stadium by LDA Lahore.

Acknowledgments: This research acknowledges the "Rainwater Harvesting Pilot Project at Gaddafi Stadium Lahore" under LDA Lahore. The author also acknowledges WASA Lahore and PMD office Lahore for the provision of data related to this research. The author is thankful to the whole team of Pyramid Construction for the field survey and construction and designing of recharge wells and collection of data.

Conflicts of Interest: The authors declare no conflict of interest.

\section{References}

1. UN-HABITAT. Blue Drop Series on Rainwater Harvesting and Utilization-Book 3: Project Managers and Implementation Agency; UN-Habitat, United Nations Centre for Human Settlements: Nairobi, Kenya, 2005; p. 101. ISBN 9211318289. HS Number: 832/06E.

2. Konikow, L.F.; Kendy, E. Groundwater depletion: A global problem. Hydrogeol. J. 2005, 13, 317-320. [CrossRef]

3. Wada, Y.; Van Beek, L.P.H.; Bierkens, M.F.P. Nonsustainable groundwater sustaining irrigation: A global assessment. Water Resour. Res. 2012, 48, 1-18. [CrossRef]

4. Rai, R.K.; Neupane, K.R.; Bajracharya, R.M.; Dahal, N.; Shrestha, S.; Devkota, K. Economics of climate adaptive water management practices in Nepal. Heliyon 2019, 5, e01668. [CrossRef] [PubMed]

5. Dwivedi, S.N.; Shukla, R.R.; Singh, R.; Adhikari, S.K.; Nambi, K.A.; Purty, S.S.; Roy, G.K. Determining the Recharging Capacity of an Injection Well in a Semi-confined Alluvial Aquifer. Curr. Sci. 2015, 109, 1177-1181. [CrossRef]

6. van Meter, K.J.; Basu, N.B.; Tate, E.; Wyckoff, J. Monsoon harvests: The living legacies of rainwater harvesting systems in South India. Environ. Sci. Technol. 2014, 48, 4217-4225. [CrossRef] [PubMed]

7. Marwa, J.; Lufingo, M.; Noubactep, C.; Machunda, R. Defeating fluorosis in the East African Rift Valley: Transforming the Kilimanjaro into a rainwater harvesting park. Sustainability 2018, 10, 4194. [CrossRef]

8. Lahore Development Authority (LDA). Government of Punjab Lahore, Pakistan. 2014. Available online: https://www.lda.gop.pk/ (accessed on 6 October 2014).

9. Water and Sanitation Agency, Lahore (WASA). Head office of Water and Sanitation Authority, t31-B Zahoor Elahi Rd, Block B Gulberg 2, Lahore, Punjab 54660. 2013. Available online: https://wasa.punjab.gov.pk/ (accessed on 4 July 2013).

10. World Wide Fund for Nature (WWF). A Special Report: Pakistan's Waters at Risk, Water and Health Related Issues in Pakistan and Key Recommendations, Major Water Sectors in Pakistan; WWF: Ferozepur Road Lahore, Pakistan, 2015; pp. 5-6.

11. Gade, A.D. Agricultural Transformation in India since Independence; Ashok, Yakkaldevi: India, 2017; p. 190.

12. Mays, L.; Antoniou, G.P.; Angelakis, A.N. History of water cisterns: Legacies and lessons. Water 2013, 5 , 1916-1940. [CrossRef]

13. The Texas Manual on Rainwater Harvesting, 3rd ed.; Texas Water Development Board: Austin, TX, USA, 2005.

14. Vieira, A.S.; Beal, C.D.; Ghisi, E.; Stewart, R.A. Energy intensity of rainwater harvesting systems: A review. Renew. Sustain. Energy Rev. 2014, 34, 225-242. [CrossRef] 
15. Belmeziti, A.; Olivier, C.; Bernard, D.G. A new methodology for evaluating potential for potable water savings (PPWS) by using rainwater harvesting at the urban level: The case of the municipality of Colombes (Paris region). Water 2013, 5, 312-326. [CrossRef]

16. Liaw, C.H.; Chiang, Y.C. Dimensionless analysis for designing domestic rainwater harvesting systems at the regional level in northern Taiwan. Water 2014, 6, 3913-3933. [CrossRef]

17. Campisano, A.; Gnecco, I.; Modica, C.; Palla, A. Designing domestic rainwater harvesting systems under different climatic regimes in Italy. Water Sci. Technol. 2013, 67, 2511-2518. [CrossRef] [PubMed]

18. Hajani, E.; Rahman, A. Reliability and cost analysis of a rainwater harvesting system in peri-urban regions of greater Sydney, Australia. Water 2014, 6, 945-960. [CrossRef]

19. Rahman, A.; Keane, J.; Imteaz, M.A. Rainwater harvesting in Greater Sydney: Water savings, reliability and economic benefits. Resour. Conserv. Recycl. 2012, 61, 16-21. [CrossRef]

20. Ghisi, E.; Tavares, D.F.; Rocha, V.L. Rainwater harvesting in petrol stations in Brasília: Potential for potable water savings and investment feasibility analysis. Resour. Conserv. Recycl. 2009, 54, 79-85. [CrossRef]

21. Li, X.; Gong, J. Compacted micro-catchments with local earth materials for rainwater harvesting in the semiarid region of China. J. Hydrol. 2002, 257, 134-144. [CrossRef]

22. Yuan, T.; Fengmin, L.; Puhai, L. Economic analysis of rainwater harvesting and irrigation methods, with an example from China. Agric. Water Manag. 2003, 60, 21-226. [CrossRef]

23. Sazakli, E.; Alexopoulos, A.; Leotsinidis, M. Rainwater harvesting, quality assessment and utilization in Kefalonia Island, Greece. Water Res. 2007, 41, 2039-2047. [CrossRef] [PubMed]

24. Goel, A.K.; Kumar, R. Economic analysis of water harvesting in a mountainous watershed in India. Agric. Water Manag. 2005, 71, 257-266. [CrossRef]

25. Pandey, P.K.; Panda, S.N.; Panigrahi, B. Sizing on-farm reservoirs for crop-fish integration in rain-fed farming systems in Eastern India. Biosyst. Eng. 2006, 93, 475-489. [CrossRef]

26. Islam, M.M.; Chou, F.F.; Kabir, M.R.; Liaw, C.H. Rainwater: A potential alternative source for scarce safe drinking and arsenic contaminated water in Bangladesh. Water Resour. Manag. 2010, 24, 3987-4008. [CrossRef]

27. Ashiq Ur Rahman, Md.; Shafiqur Rahman, A.S.M. Rainwater Harvesting in Bangladesh: Potentials, Challenges and Stakeholders' Responses; Ashiq Ur Rahman, Md., Shafiqur Rahman, A.S.M., Eds.; WaterAid: Dhaka, Bangladesh, 2013.

28. Mohammad, H.R.M.; Bahram, S.; Fereshte, H.F. Assessment of residential rainwater harvesting efficiency for meeting non-potable water demands in three climate conditions. Resour. Conserv. Recycl. 2013, 73, 86-93.

29. Fooladman, H.R.; Sepaskhah, A.R. Economic analysis for the production of four grape cultivars using micro-catchment water harvesting systems in Iran. J. Arid. Environ. 2004, 58, 525-533. [CrossRef]

30. Ahmed, A.; Farooq, A. Study of rainwater harvesting potential in an industrial area using stormwater management model (SWMM V 5.0)—A case study of Quaid-E-Azam Apparel Park, Sheikhupura, Punjab, Pakistan. Int. J. Environ. Eng. 2018, 9, 185-198. [CrossRef]

31. Siddiqui, R.; Siddiqui, S. Assessing the Rooftop Rainwater Harvesting Potential in Urban Residential Areas of Pakistan: A Case Study of Model Town, Lahore, Pakistan. Int. J. Econ. Environ. Geol. 2018, 9, 11-19.

32. Hassan, I. Rainwater Harvesting-an alternative water supply in the Future for Pakistan. J. Biodivers. Environ. Sci. 2016, 8, 213-222.

33. Song, J.; Han, M.; Kim, T. Rainwater harvesting as a sustainable water supply option in Banda Aceh. Desalination 2009, 248, 233-240. [CrossRef]

34. Macomber, P.S.H. Guidelines on Rainwater Catchment Systems for Hawaii; College of Tropical Agriculture and Human Resources (CTAHR), University of Hawai'i at Mānoa: Honolulu, HI, USA, 2010; p. RM-12.

35. Black, J.; Malesu, M.; Oduor, A.; Cherogony, K.; Nyabenge, M. Rainwater Harvesting Inventory of Kenya an Overview of Techniques, Sustainability Factors, and Stakeholders; World Agroforestry Centre (ICRAF): Nairobi, Kenya, 2012.

36. Areerachakul, N. Overviews of Rainwater Harvesting and Utilization in Thailand: Bangsaiy Municipality. Int. J. Environ. Ecol. Eng. 2013, 7, 1848.

37. Monjaiang, P.; Limphitakphong, N.; Kanchanapiya, P.; Tantisattayakul, T.; Chavalparit, O. Assessing Potential of Rainwater Harvesting: Case Study Building in Bangkok. Int. J. Environ. Sci. Dev. 2018, 9, 222-225. [CrossRef] 
38. Herrmann, T.; Schmida, U. Rainwater Utilisation in Germany: Efficiency, Dimensioning, Hydraulic and Environmental Aspects. Urban Water 1999, 1, 307-316. [CrossRef]

39. Wu, R.-S.; Molina, G.L.L.; Hussain, F. Optimal Sites Identification for Rainwater Harvesting in Northeastern Guatemala by Analytical Hierarchy Process. Water Resour. Manag. 2018, 32, 4139. [CrossRef]

40. Li, Z.; Fergal, B.; Anthony, R. Rainwater harvesting and greywater treatment systems for domestic application in Ireland. Desalination 2010, 260, 1-8. [CrossRef]

41. Abdulla, F.A.; Al-Shareef, A.W. Roof rainwater harvesting systems for household water supply in Jordan. Desalination 2009, 243, 195-207. [CrossRef]

42. Sturm, M.; Zimmermann, M.; Schütz, K.; Urban, W.; Hartung, H. Rainwater harvesting as an alternative water resource in rural sites in central northern Namibia. Phys. Chem. Earth. 2009, 34, 776-785. [CrossRef]

43. Singapore Water Story. Available online: https://www.pub.gov.sg (accessed on 14 November 2018).

44. Dealing with Water Scarcity in Singapore: Institutions, Strategies, and Enforcement. Available online: http://www.siteresources.worldbank.org (accessed on July 2006).

45. Lani, N.H.M.; Yusop, Z.; Syafiuddin, A. A Review of Rainwater Harvesting in Malaysia: Prospects and Challenges. Water 2018, 10, 506. [CrossRef]

46. Kahinda, J.M.; Taigbenu, A.E.; Boroto, J.R. Domestic Rainwater harvesting to improve water supply in rural South Africa. Phys. Chem. Earth. 2007, 32, 1050-1057. [CrossRef]

47. Domènech, L.; Saurí, D. A comparative appraisal of the use of rainwater harvesting in single and multi-family buildings of the Metropolitan area of Barcelona (Spain): Social experience, drinking water savings and economic costs. J. Clean. Prod. 2011, 19, 598-608. [CrossRef]

48. Villareal, E.L.; Dixon, A. Analysis of a rainwater collection system for domestic water supply in Ringdansen, Norrköping, Sweden. Build. Environ. 2005, 40, 1174-1184. [CrossRef]

49. Fewkes, A. Modeling the performance of rainwater collection systems: Towards a generalized approach. Urban Water 1999, 1, 323-333. [CrossRef]

50. Jones, M.P.; Hunt, W.F. Performance of rainwater harvesting systems in the south eastern United States. Resour. Conserv. Recycl. 2010, 54, 623-629. [CrossRef]

51. Handia, L.; Tembo, J.M.; Mwiindwa, C. Potential of Rainwater harvesting in urban Zambia. Phys. Chem. Earth. 2003, 28, 893-896. [CrossRef] 